Elsevier required licence: (C) <2018>. This manuscript version is made available under the CC-BY-NC-ND 4.0 license http://creativecommons.org/licenses/by-nc-nd/4.0/ 


\title{
The impact of dividend imputation on corporate tax avoidance: The case for
}

\author{
shareholder value \\ Ross McClure, Roman Lanis, Peter Wells and Brett Govendir \\ University of Technology Sydney
}

November 2017

\begin{abstract}
The objective of this paper is to evaluate whether dividend imputation, whereby tax credits may be passed on to shareholders for corporate tax paid, impacts corporate tax avoidance. This is undertaken with a pooled cross-sectional research design evaluating differences in tax avoidance across firms where there are significant differences in corporate tax avoidance incentives. Specifically, potential differences arise between firms paying dividends with tax credits, paying dividends without tax credits, and not paying dividends. Results suggest that firms paying dividends with tax credits attached are less likely to engage in tax avoidance with an average cash effective tax rate up to 16.9 percentage points higher than firms that pay dividends without tax credits, and up to 14.7 percentage points higher than firms that do not pay dividends at all. Accordingly, this provides insights into the effectiveness of dividend imputation in mitigating corporate tax avoidance, as well as providing support for the continuance of dividend imputation in Australia. Additionally, a positive association is found to exist between outside directors and corporate tax avoidance, extending to firms paying dividends with tax credits where dividend imputation is expected to mitigate such a relation. In combination, these results suggest heterogeneity of costs and benefits of tax avoidance and this is a challenge in evaluating corporate tax aggressiveness generally, and the impact of corporate governance on corporate tax avoidance in particular.
\end{abstract}

Keywords: Dividend imputation; corporate tax avoidance;

JEL Classification: H21; H25; H26; G35; G38; M41 


\section{The impact of dividend imputation on corporate tax avoidance: The case for}

\section{shareholder value}

\section{Introduction}

The literature suggests that dividend imputation may be associated with lower levels of tax avoidance. However, there are numerous limitations in these studies. Amiran, Bauer and Frank (2016) rely on a cross country design, and both Wilkinson, Cahan and Jones (2001) and Ikin and Tran (2013) use limited samples which are unlikely to be representative of the overall population. Further, all three papers lack a theoretical foundation linking tax avoidance and dividend imputation, and provide no evidence of economic significance. Amiran et al. (2016) in particular, and with little justification, implicitly assume that under dividend imputation, managers in all firms will not engage in tax avoidance, as it is ineffective in increasing shareholders' wealth (Lasfer, 1996; Amiran et al., 2016). As a consequence, they ignore differences from the impact of dividend imputation across firms, and in particular, firms not paying dividends, as the effects of tax-induced dividend clienteles and the constraints on the impact of imputation are not considered.

The objective of this paper is to evaluate corporate tax avoidance separately across firms paying dividends with tax credits, dividends without tax credits, and not paying dividends, where significant differences in the impact of dividend imputation on the incentives for corporate tax avoidance exist. ${ }^{1}$ Additionally, this study evaluates the tax avoidance strategies available in an imputation setting that are in the best interests of shareholders, by controlling for outside director monitoring. This research has important policy implications given that the

\footnotetext{
${ }^{1}$ Appendix A contains an overview of the systems and operations of dividend imputation in Australia.
} 
recent Australian Treasury Department discussion paper (Treasury, 2015) proposes the abolition of dividend imputation in Australia. ${ }^{2}$

Research into corporate has tax gained in significance due to the increasing incidence and magnitude of corporate tax avoidance. ${ }^{3}$ In response, the OECD initiated the Base Erosion and Profit Shifting (BEPS) project proposes greater international co-operation and co-ordination to combat global corporate tax aggressiveness. Alternate international responses include the U.K. Finance Act, 2015, and the Australian Tax Laws Amendment (Combating Multinational Tax Avoidance) Act, 2015. One commonality is that these responses represent a transactionbased approach that attempts to close opportunities for inter-jurisdictional tax arbitrage, without addressing the fundamental underlying incentives that drive corporate tax avoidance. Conversely, dividend imputation impacts these incentives by allowing firms to provide the same level of potential benefit to shareholders without incurring the potential costs associated with tax avoidance. Critically, the impact of dividend imputation on the incentives for corporate tax avoidance has not been rigorously developed on a theoretical basis, or subjected to robust empirical analysis.

Australia's dividend imputation arrangements have been operating since 1987 and provide an ideal setting where such analysis can be undertaken, since the $\operatorname{cost}^{4}$ of corporate tax borne by shareholders is reduced for those firms paying dividends with tax credits, and this impacts the incentives for corporate tax avoidance. Critically, this impact will not be uniform across firms, as not all shareholders can fully utilize the tax credits resulting from dividend

\footnotetext{
2 The Treasury paper released in March 2015 argues that imputation is expensive, costing government revenues an estimated AUD19 billion per year, and that it does little to attract foreign direct investment to Australia, as tax credits provide little value for non-resident investors.

${ }^{3}$ For example, the corporate contribution to total tax revenues in the U.S. declined by a quarter between 1996 and 2012. At the same time profits held by multinational entities in low tax jurisdictions increased fourfold to over \$1.9 trillion in the decade to 2012 (Levin, 2013).

${ }^{4}$ Corporate tax can be viewed as a cost to shareholders, as it reduces profits available for distribution and therefore reduces their wealth (for example, see Rego and Wilson [2012]). This is not to be confused with the costs associated with engaging in tax avoidance, which includes transaction costs, legal fees, penalties and reputational costs that are incurred by the firm.
} 
imputation, and therefore may result in significant heterogeneity of the costs and benefits of corporate tax avoidance across firms in an imputation environment. ${ }^{5}$

For firms that do not pay dividends, or those that pay dividends without tax credits, ${ }^{6}$ incentives for corporate tax avoidance remain the same as they would within a "classical" tax regime. ${ }^{7}$ Managers' decisions about corporate tax avoidance are dictated by a comparison of the anticipated tax savings that can be passed to shareholders, with the potential costs and risks that may be incurred by the firm. However with imputation, firms that pay dividends with tax credits provide benefits that mitigate the cost of corporate tax to shareholders, without incurring any of the potential costs associated with engaging in tax avoidance. For firms that pay dividends with tax credits, tax paid on corporate profits is "not really company tax but rather a collection of personal tax at the company level" (Officer, 1994, p.4). This changes a firm's incentives from maximising after-tax earnings to maximising pre-tax earnings (Bellamy, 1994). As tax credits are generated by the amount of corporate taxes paid, this potentially makes tax avoidance and the distribution of tax credits, especially at the maximum rate, ${ }^{8}$ mutually exclusive corporate strategies. ${ }^{9}$

\footnotetext{
${ }^{5}$ Tax credits (known as "franking" credits) are the basis of dividend imputation and the mechanism through which taxes paid by firms are passed through to the benefit of shareholders.

${ }^{6}$ The payment of dividends with tax credits is used as the proxy for the effects of dividend imputation in the analysis of corporate tax avoidance. For a discussion of the effects of dividend imputation on dividend policy, see Pattenden and Twite (2008). An analysis of the determinants of dividend policy under imputation is beyond the scope of this paper.

${ }^{7}$ For a "classical" dividend taxation system, corporate profits are taxed first within the firm through company income tax, and then again in the hands of the shareholders, as income on their personal tax return, when distributed as dividends.

${ }^{8}$ See Appendix A for an overview of dividend imputation in Australia, including an explanation of the maximum allowable tax credits.

${ }^{9}$ While the relation between tax credits and dividends poses further questions regarding the impact of imputation on corporate dividend policy, the scope of this paper is limited to evaluating the impact of imputation on corporate tax strategies and associated incentives, whilst allowing for the mediating effects of corporate governance factors and managerial incentives. See Pattenden and Twite (2008) for an evaluation of the impact of imputation on dividend policy in Australia. While dividend policy is related to corporate tax strategies through imputation, the determinants of corporate payout policy under imputation is beyond the scope of this paper.
} 
Amiran et al. (2016) evaluated the impact of dividend imputation on corporate tax avoidance using a difference in differences approach across countries where dividend imputation was removed in favour of a "classical" dividend tax system. Consequently, this leads to the unsupported contention that the costs and benefits of tax avoidance are homogenous for all firms, whether in a classical or imputation setting. On the one hand, as corporate tax avoidance increases the return to shareholders it has been identified as in the best interest of shareholders of all firms in a classical tax system (Lasfer, 1996; Amiran et al., 2016). Evidence consistent of an association between monitoring by outside directors, and corporate tax avoidance exists (Jiminez-Angueira, 2008; Desai and Dharmapala, 2006, 2008; Minnick and Noga, 2010; Lanis and Richardson, 2011; Armstrong et al., 2015). This is a plausible assumption given that the costs and benefits of tax avoidance in a classical regime are likely to have greater homogeneity, due to less identifiable and measurable determinants.

On the other hand, Amiran et al. (2016) contend that within an imputation setting, corporate tax avoidance reduces shareholder returns, and therefore managers in all firms will not engage in tax avoidance as it is ineffective in increasing shareholders' wealth. However, this study expects that this assumption is more tenuous in an imputation setting due to the existence of tax-induced dividend clienteles ${ }^{10}$ and constraints on the ability of firms to fully distribute tax credits. As a result, a substantial number of firms either pay no dividends, or pay dividends without tax credits attached, and this instigates a diversity of outcomes with respect to tax avoidance strategies. In the Australian imputation setting there are constraints

\footnotetext{
${ }^{10}$ A further example of the clientele effect that explains why a significant number of firms pay no tax credits in Australia is that costs of corporate tax avoidance may be heterogeneous because they have low or zero potential costs associated with adopting corporate tax avoidance strategies (Austin and Wilson 2015; Hanlon and Slemrod 2009). For example, there is evidence that the costs and risks associated with corporate tax avoidance might not be homogeneous across firms in different industries (Austin and Wilson, 2015; Edwards et al., 2016; Guenther et al., 2016; Hanlon \& Slemrod, 2009). These firms may also be responding to shareholders who are unable to access the value of the tax credits, such as foreign residents, or individuals subject to high marginal tax rates. In this regard, it should be noted that there is strong evidence that imputation creates tax-induced dividend clienteles (Bellamy, 1994; Henry, 2011; Jun, Gallagher and Partington, 2011). Therefore, shareholders' residency and individual tax circumstances may induce the formation of these dividend clienteles.
} 
on the ability of firms to distribute all the tax credits. For instance, reductions in the corporate tax rate may provide incentives for managers of firms that pay dividends with tax credits attached to engage in some level of tax avoidance. Australia provides an ideal setting to resolve these tensions and to test extant research assumptions, as the heterogeneity in the costs and benefits of tax avoidance are easily identifiable and measurable in an imputation setting. These issues are addressed by evaluating corporate tax avoidance separately for firms paying dividends with tax credits, dividends without tax credits and not paying dividends. Further, this classification permits the evaluation of the role of outside directors in monitoring tax strategies where controls for potential heterogeneity in the costs and benefits of corporate tax avoidance are included with respect to each of these categories. ${ }^{11}$

Based on a sample of 4,729 firm-year observations between 2004 and 2015, variations in corporate tax avoidance are evaluated across firms (1) not paying dividends, (2) paying dividends without tax credits, and (3) paying dividends with tax credits. If dividend imputation reduces the incentives for tax avoidance, different levels of tax avoidance are expected between these three groups of firms. Notably, the results from the evaluation are economically significant, as firms paying dividends with tax credits attached have an average effective tax rate (ETR) almost seventeen percentage points higher than those paying dividends without tax credits. Firms paying dividends without tax credits have an average ETR approximately two percentage points lower than firms that do not pay dividends. However, even within those firms that distribute tax credits, there is wide variation exhibited in the ETR's. This extends the extant literature, suggesting a more nuanced association between dividend imputation and corporate tax avoidance. While this intra-group variation

\footnotetext{
${ }^{11}$ Board independence has been promoted as a shareholder wealth-maximizing mechanism through improved monitoring of managers and improved decision-making (Hermalin \& Weisbach 1988). It is also the most widely associated corporate governance mechanism with respect to corporate tax avoidance (Minnick \& Noga, 2010; Lanis and Richardson, 2011; Armstrong et al., 2015).
} 
also occurs for firms that pay dividends without tax credits and those that do not pay dividends. Further evaluation of these variations is beyond the scope of this paper.

After controlling for the impact of dividend imputation on corporate tax avoidance a positive association between the proportion of outside directors and the level of corporate tax avoidance is exhibited. This confirms the view that the costs and benefits of tax avoidance are heterogeneous, and also suggests that in general, managers in Australian firms still pursue policies of tax avoidance in order to maximise shareholder wealth, despite the imputation environment. This finding is inconsistent with the implicit claims in Lasfer (1996) and Amiran et al. (2016). Specifically, for firms that are not paying dividends, or paying dividends without tax credits, the incentives for corporate tax avoidance remain consistent with those in operating within a 'classical' dividend tax system, with this paper finding that outside director monitoring is associated with increased tax avoidance in those firms as suggested by Amiran et al. (2016). However, for firms paying dividends with tax credits, outside director monitoring is also found to be associated with increased tax avoidance, and the association is not significantly different than for firms not paying dividends or paying dividends without tax credits. This is also inconsistent with Amiran et al. (2016), suggesting that the imputation environment in Australia has built-in constraints preventing firms from fully streaming the benefit from paying corporate tax by way of dividends with tax credits attached. That is, these constraints, above some minimum payment of tax in order to pay a given tax credit, still provide management with enough incentive to pursue tax avoidance to increase benefits for shareholders. Thus, even if imputation sets a ceiling on the level of tax avoidance, it does not fully eliminate the benefits thereof.

In order to confirm the veracity of the results and the supporting theoretical arguments, a series of additional analyses are included. They are an examination of whether heterogeneity 
of the costs associated with tax avoidance (Austin and Wilson, 2017; Hanlon \& Slemrod, 2009; Dyreng et al. 2014) impacts the incentives for tax avoidance and produces the variation in tax avoidance outcomes. There is no support found for this proposition. Assessing the level of foreign ownership between the different groups of firms supports the existence of a clientele effect that is associated with the distribution of tax credits. Other analyses indicate that the Global Financial Crisis has reduced the overall level of tax avoidance for all firms, with no differential impact on those firms that pay dividends with tax credits. Untabulated annual cross-sectional regressions of the baseline regressions are consistent with the main results across all firm-years. While results from these tests provide limited support for the independence of the main variables, concerns of endogeneity, reverse causality and selection bias are also addressed and the results remain consistent, confirming the baseline results.

This paper makes a number of important contributions to the ongoing policy debate in Australia regarding dividend imputation (Treasury, 2015), and to the scant academic literature on firm incentives for tax avoidance and the role of imputation and corporate governance in ameliorating those incentives. In this paper, the assertions raised in Wilkinson et al. (2001), Ikin and Tran (2013) and Amiran et al. (2016) are both rigorously evaluated and extended by: first, ascertaining the incentive mechanisms that drive tax avoidance; second, providing robust empirical evidence as to the association between imputation and tax avoidance; and third, quantifying the economic impact of dividend imputation on tax avoidance in Australia. Hence, this paper contributes to the literature on corporate tax avoidance, and in particular, the incentives for firms to engage in aggressive tax strategies. Additionally, this paper is one of the few that examines the effectiveness of a regulatory response to tax avoidance. ${ }^{12}$ Critically, this paper is the first to empirically evaluate a number

\footnotetext{
${ }^{12}$ Exceptions are the evaluation of the U.S. Tax Reform Act, 1986 (e.g. Auerbach and Slemrod, 1997; Givoly, Hayn, Ofer, and Sarig, 1992) and effectiveness of the U.S. Job Creation Act, 2004 (e.g. Blouin and Krull, 2009; Clausing, 2005)
} 
of previously unsubstantiated assumptions with respect to how managers behave with respect to corporate tax avoidance in order to maximise shareholder wealth within the context of monitoring by outside directors. Implicitly the mixed results achieved in the extant literature are reconciled in the Australian imputation environment which provides an ideal setting for resolving much of the tension produced within the corporate governance and tax avoidance discourse to date.

The remainder of the paper is structured as follows: Section 2 outlines the relevant literature and hypothesis development; Section 3 describes the research design and proxies for tax avoidance; Section 4 presents the results, and Section 5 contains the conclusions.

\section{Theory and Hypothesis Development}

In their review of tax research in accounting, Hanlon and Heitzman (2010) call for accounting researchers to examine "real" corporate decisions, and the incentive structures around corporate tax reporting. Both corporate tax avoidance and dividend imputation contain incentives regarding the amount of tax a firm pays on its profits, and are potentially of first order importance in other strategic decisions (Allen and Michaely, 2003; Poterba, 2004). Dividend imputation alters incentives for managers, corporations and shareholders when making decisions about investment opportunities, capital structures, and dividend policies, as well as their tax strategies (Amiran et al. 2016). Despite this, there is inadequate rigorous research into the effects of dividend imputation on the incentives to engage in corporate tax avoidance or whether managers pursue these tax strategies in the shareholders best interests.

Dividend imputation allows firms to avoid the costs of taxation by allowing firms to pass the costs on to shareholders with tax credits attached to their dividends, representing the 
corporate tax paid on the profits distributed. To the extent that shareholders can access the value of corporate tax paid, imputation diminishes the benefits of engaging in tax avoidance. As tax avoidance may also incur substantial costs (Hanlon and Heitzman, 2010; Hanlon and Slemrod, 2009), imputation is likely to diminish the incidence of such behaviour. Critically, the modified treatment of corporate tax paid within an imputation environment changes a firm's motivations from maximising after-tax earnings to maximising pre-tax earnings (Bellamy, 1994). In order to maximise shareholder wealth, firms operating in an imputation environment should concentrate on maximising pre-tax earnings and paying tax on their profits to allow for tax credits to be distributed at the maximum rate. ${ }^{13}$ While this suggests that dividend imputation mitigates the incentives for corporate tax avoidance, the extent will be limited by the existence of tax-induced dividend clienteles, as not all shareholders are able to fully utilize their tax credits, and by constraints on the ability of firms to distribute tax credits.

\section{The Costs and Benefits of Corporate Tax Avoidance}

While corporate tax avoidance ${ }^{14}$ has at times been portrayed as managers rent extraction of net benefits from governments on behalf of shareholders (e.g., Rego and Wilson, 2012), it is questionable whether these strategies are always in the best interest of shareholders (Amiran et al., 2016; Desai and Dharmapala, 2009; Slemrod, 2004). There are obvious benefits to firms engaging in tax avoidance such as an increase in cash and liquidity (Saavedra, 2013), increased after-tax profits, and a reduced tax liability (Hanlon and Slemrod, 2009). Further, the reduction in a firm's ETR provided by tax avoidance is potentially a positive signal to

\footnotetext{
${ }^{13}$ This is generally equal to the current corporate tax rate. A full explanation of the maximum rate is provided in Appendix A.

${ }^{14}$ Hanlon and Heitzman (2010) state "that there are no universally accepted definitions of, or constructs for, tax avoidance or tax aggressiveness; the terms mean different things to different people.” (p.137). Nevertheless, this paper follows Hanlon and Heitzman (2010) and defines tax avoidance very broadly reflecting all transactions that reduce a firm's explicit tax liability, including both certain and uncertain tax positions that may or may not be challenged by tax authorities. Additionally, the cash effective tax rates used in this research are a clearer signal of tax avoidance as they are not confounded by accounting accruals (Dyreng, Hanlon and Maydew, 2008).
} 
investors, thereby reducing the cost of equity capital (Chi, Pincus and Teoh, 2014; Inger, 2014; McGuire, Omer and Wilde, 2014). These benefits provide strong incentives for firms to engage in tax avoidance.

Conversely, there are potentially significant costs and risks for firms engaging in corporate tax avoidance. These potential costs include increased legal and transaction costs (Rego and Wilson, 2012; Wilson, 2009), and hostility towards the firm, including reputational damage among its various stakeholders (Boone et al., 2013; Lanis and Richardson, 2013). It can also leave firms exposed to higher levels of political and regulatory risk, as well as social sanctions such as boycotts (Hoi, Wu, and Zhang, 2013). If tax avoidance is detected and the tax position found to be unsupported, it can result in further financial penalties as well as the potential for increased damage to the firm's reputation (Desai and Dharmapala, 2006; Hanlon and Slemrod, 2009; Lanis and Richardson, 2013). Managers implementing tax avoidance strategies are also personally exposed to the risk of penalties and fines, and damage to their reputations. As the risks associated with detection of tax avoidance falls more heavily on the individual manager than on the firm itself, substantial compensation costs are required to offset the higher risks (Chen and Chu, 2005). Therefore, either the benefits gained from tax avoidance need to significantly exceed the potential costs in order to encourage managers and firms to engage in tax avoidance, or the costs would need to be insignificant. ${ }^{15}$ It is also likely that the costs and benefits of corporate tax avoidance will somewhat differ across firms reflecting firm-level characteristics.

Tax avoidance also potentially involves a number of additional, less explicit costs that can be detrimental to shareholders interests and reduce net benefits flowing to shareholders from corporate tax avoidance. Low ETR's are associated with higher levels of debt in capital

15 There is evidence that the costs of tax avoidance, particularly reputational costs, are not homogeneous amongst firms (Hanlon \& Slemrod, 2009; Guenther et al. 2016) and this may partially explain the anomaly of firms that both pay corporate taxes and distribute dividends without attaching tax credits. 
structures (Graham and Tucker, 2006; Harrington and Smith, 2012), lower earnings persistence (Hanlon, 2005) and higher stock volatility (Kim, Li, and Zhang, 2011). Additionally, in poorly governed firms, secrecy surrounding tax avoidance can be exploited to obscure rent extraction by managers, resulting in future negative abnormal returns (Desai and Dharmapala, 2006). Also, tax avoidance has been used to mask the hoarding of bad news by managers, leading to increased risk of a stock price crash (Kim et al., 2011). As with explicit costs, these costs might not be homogeneous between firms and industries, and recent evidence suggests the relation between tax avoidance and stock prices might not be linear (Cook, Moser, and Omer, 2015), as it appears investors reward lower levels of tax avoidance but disapprove of higher levels. However, as corporate tax avoidance has a detrimental effect on government revenues, it may provoke a regulatory response that can adversely impact firms engaging in certain tax avoidance strategies.

With dividend imputation, some of the potentially significant costs associated with tax avoidance need not be incurred if the benefits of such activities are reduced by passing them on to shareholders through the payment of dividends with tax credits. Firms can provide, ceteris paribus, the same level of benefits to shareholders as they can through tax avoidance, without incurring any of the potential costs. The extent of the benefits to shareholders is only constrained by limits on firms' ability to distribute tax credits.

\section{Dividend Imputation in Australia}

Dividend imputation was introduced in Australia in $1987,{ }^{16}$ primarily to provide relief to individual resident shareholders from double taxation of corporate profits. ${ }^{17}$ Essentially, shareholders receive a tax credit attached to their dividends that reflects the extent to which corporate tax has been paid on that portion of profit. Consequently, corporate profit will

\footnotetext{
${ }^{16}$ See Appendix A for a description and explanation of the Australian dividend imputation system.

${ }^{17}$ Under a classical dividend taxation system, profits are taxed firstly in the hands of the company, and then again in the hands of investors, when distributed as dividends.
} 
ultimately be taxed only at the individual shareholders' marginal tax rate. However, corporations can only distribute tax credits to the extent that corporate tax has been paid.

Dividend payments are the mechanism through which the benefit of corporate tax payments is passed to shareholders. Hence, the level of tax credits that can be distributed is a function of dividend distribution, with tax credits subject to a maximum rate of the dividend multiplied by the company statutory tax rate. However, while this mechanism limits tax credits to the corporate tax rate, it does not constrain the payment of dividends, and they may be paid with only partial tax credits or no tax credits. Following legislative changes, it is no longer possible to selectively stream tax credits to specific categories of shareholders. In situations where corporate tax payments exceed the value of the tax credits distributed, excess tax credits may be accrued and carried forward for future distribution, although it should be noted that there are limits on the rate at which tax credits can be distributed, and their value to shareholders diminishes over time. ${ }^{18}$

The benefit of the tax credit is realized by individual shareholders when determining their personal tax obligations. For Australian resident shareholders the dividend and the tax credits are included in the shareholders' taxable income, and credit is given for the tax paid. When imputation was introduced there was no provision for tax credits in excess of the shareholders' tax liability to be refunded to the shareholder. In these circumstances, the shareholder would not realize the full value of the tax credit, with excess value being lost. This may have created an incentive for firms to pay dividends with only partial tax credits, or without tax credits. However, since 2000, the value of excess tax credits is refundable for resident shareholders removing this incentive. While there has been refinement to the

\footnotetext{
${ }^{18}$ Over the period $2004-2011,71 \%$ of corporate tax paid was distributed as tax credits attached to dividends, and an estimated $62.3 \%$ of these tax credits were redeemed by shareholders (Hathaway, 2013, p.7). However, that level of redemption may be understated, as Lally (2012), using data from the Australian Tax Office, estimated the redemption rate to be has high as $81 \%$ during the period from 2000 to 2010 .
} 
regulations addressing dividend imputation, it has generally operated in such a manner as to give shareholders tax credits equal to the corporate taxes paid on the dividends.

As tax credits are non-redeemable for non-resident shareholders, imputation discriminates against these shareholders potentially creating tax-induced dividend clienteles based on an investors' tax residency (Bellamy, 1994; Heaney, 2011; Jun et al., 2011). ${ }^{19}$ While a number of strategies had been developed by firms and shareholders to access the full value of tax credits, those strategies have been largely abandoned as a result of legislative changes to dividend imputation between 1998 and 2001. There is now little value in tax credits for nonresident shareholders. This splits Australian equity investors into two groups: those that can access the full value of the tax credits; and those that gain little or no value, creating two investor clienteles. To provide maximum benefits to their shareholders, firms either: (1) opt in to dividend imputation, pay the corporate tax rate on earnings, and distribute earnings with the maximum rate of tax credits attached; or (2) they opt out, and attempt to provide increased benefits through corporate tax avoidance, regardless of whether they pay dividends or not.

Much of the literature on tax-induced dividend clienteles examines arbitrage between capital gains tax and dividend tax, within a "classical" tax regime (Elton and Gruber, 1970; Dhaliwal, Erickson and Trezevant, 1999; Desai and Jin, 2011). Miller and Modigliani (1961) argue that investors should be indifferent to value gained through either dividends or capital gains if there were no taxes, or if both were taxed at the same rate. However, consistent with research in other countries, Pattenden and Twite (2008) found that, even when capital gains were taxed preferentially in Australia, firms still continued to pay dividends. This anomaly

\footnotetext{
${ }^{19}$ The discriminatory nature of imputation systems and the bias in favour of domestic investors was identified by the European Court of Justice in the late 1990's when dividend imputation systems in Europe were challenged under unfair competition/government support rules leading to the abolition of dividend imputation in a number of European countries.
} 
has been previously established and is known as the "dividend puzzle" (Black, 1976; Myers, 1984).

A possible explanation offered for the dividend puzzle is the heterogeneity of personal taxes. Some investors gain better tax outcomes through capital gains, some gain more through dividends, while others may be indifferent. Two trends could be expected to emerge simultaneously: (1) investors will gradually align with firms whose dividend policy matches their tax preferences; and (2) firms will gradually move their dividend policy towards the tax preferences of their major shareholders. Over time, alignment of investors and dividend policy will become entrenched. Dividends signal managers' private information regarding the future earnings of the firm (Bhattacharya 1979; Allen \& Michaely 2003; Coulton \& Ruddock 2011) and managers respond by setting long-term target payout ratios (Lintner, 1956). Firms reducing or eliminating dividends are punished by shareholders causing dividends to become 'sticky' over time (Lintner, 1956). This paper exploits the clientele effect in Australia by examining and comparing two groups: one that is engaging in the imputation system; and another that is not.

A second objective for the introduction of dividend imputation in Australia was to correct a bias in the previous "classical" tax system that favoured debt over equity finance (Treasury, 1986). This bias was generated by the differential tax deductibility of interest compared to dividend payments. Corporate regulators felt that Australian firms were carrying unsustainable levels of debt due to this imbalance (Treasury, 1986), with shareholders bearing most of the risk. The introduction of dividend imputation appears to have achieved this objective, as it led to a decline in the aggregate proportion of debt in corporate capital structures in Australia (Twite, 2001). The decline was more significant for firms with higher ETR's, which indicates that the tax shield effect of debt appears to have been an incentive to 
firms to increase their levels of debt for no other purpose than to reduce their tax liabilities. While the use of debt can magnify the return on investment for shareholders, this is conditional on the funds being employed productively and generating a positive rate of return.

Some prior research purports to have found evidence that Australian publicly listed firms may have changed their tax strategies in response to amendments to dividend imputation in the late 1990's and early 2000's (Wilkinson, Cahan and Jones, 2001; Ikin and Tran, 2013; Amiran et al., 2016). Critically, these papers lack adequate theoretical frameworks ${ }^{20}$ linking theory to their research designs, and challenging their conclusions. They also suffer from unsubstantiated assumptions about the effects of imputation, and potentially unrepresentative or at best problematic sample selection.

Amiran et al. (2016) examined a change to the Australian imputation system in 2002, using a difference-in-differences research design. They compared the effect of the change in corporate tax avoidance in Australia after that date (treatment group), to changes in tax avoidance in other countries over the same period (control group). A major limitation with their research design, which may be a consequence of its multinational context, is the implicit assumption that the costs and benefits of corporate tax avoidance were treated as homogenous across firms, hence the impact of dividend imputation was also assumed to be uniform across firms. Notably, in this paper the sample distinguishes that $32 \%$ of firms are not paying dividends and $10 \%$ are paying dividends without tax credits. Critically, the incentives for corporate tax avoidance in these circumstances are not ameliorated by dividend

\footnotetext{
${ }^{20}$ For example, Ikin and Tran (2013) claim that they are not examining tax strategies that include "outright tax evasion such as deliberate omission of income from corporate tax returns" (p.525) but use effective tax rates as their proxy for tax strategy that includes all tax minimising strategies. They also state that "dividend imputation system eliminates the double taxation of corporate profits distributed as dividends and thus reduces management incentives to pursue costly aggressive tax strategies" (p.530) but provide no explanation of how this occurs nor do they cite any supporting evidence.
} 
imputation. Accordingly, the results from Amiran et al. (2016) may be attributable to other uncontrolled institutional differences, or the impact of dividend imputation on corporate tax avoidance may be grossly understated. A second limitation of Amiran et al. (2016) is the comparison of tax avoidance outcomes across tax jurisdictions, as it is fraught with difficulties. Not only are tax laws different in scope, applicability, and in the incentives they contain, but the compliance and enforcement regimes can also be markedly different.

A greater limitation of both Amiran et al. (2016) and Ikin and Tan (2013) were their sample periods and treatment dates. The change in the imputation laws used as the treatment effect in Amiran et al. (2016) was not the only change affecting dividend imputation between 2000 and 2003. The Australian dividend imputation regime was comprehensively overhauled between 1997 and 2002 with numerous concurrent changes occurring, some with phase-in periods of two or three years. ${ }^{21}$ These concurrent changes create large confounding effects for any event-type study during this period. Perhaps the largest effect came from reductions in the corporate tax rate, ${ }^{22}$ combined with the change to the accounting for tax credits from the assessed tax liability to a cash taxes paid basis. This included the abolition of quarantined profits with corresponding tax credits. Firms were able to distribute tax credits at a higher rate than the current tax rate with balances converted to a cash basis at the end of the three year phase in period, hence distorting any measures based on the distribution of tax credits during

\footnotetext{
${ }^{21}$ The period between 1997 and 2003 was one of intense and major change to the Australian taxation system. Some to the significant changes that affected dividend imputation were: a prohibition on trading (selling) of imputation credits by foreign investors, such as via a securities loan (1997); 45 day holding rule to qualify for imputation credits (2000); refund to shareholders for unused tax credits (2000); further limits on the trading of imputation credits by foreign investors (2002); removing the ability to "stream" tax credits to different classes of shareholders (2002); rolling balance "franking" accounts for each corporate tax entity recorded on a tax paid rather than an annual after-tax distributable profits basis (2002); tax on corporate dividend income treated the same as individual shareholders (2002); New Zealand companies become eligible for any tax paid in Australia (2003). Another major tax change that would affect both investor and corporate tax strategies was a $50 \%$ discount on capital gains income (1999) and the abolition of accelerated depreciation (1999). There was also the introduction of a broad-based consumption tax, along with the abolition or amendments to both wholesale and retail sales taxes, stamp duties and financial taxes and duties, in 2001.

${ }^{22}$ There were two reductions in the corporate tax rate: from $36 \%$ to $34 \%$ (2000); from $34 \%$ to $30 \%$ (2001). Profits were quarantined into categories depending on the tax rate that had applied to them, and depleted on a first in, first out basis..
} 
that period. Ikin and Tran (2013) used only the period from 1999 to 2003 to test their hypotheses, significantly constraining any findings due to "noise" from other changes. Problematically, some of the legislative changes had theoretically opposite implications for the incentives to engage in tax avoidance. ${ }^{23}$ The longer sample period used in this study ameliorates these impacts, with the period since 2004 being relatively stable, with very little further change to Australian corporate and investor taxes, or to the corporate tax rate.

A further issue for Ikin and Tran (2013) is that the restrictions on the sample selection may have produced an unrepresentative sample. They included only large Australian firms, including financial and utilities firms, with all data available between 1999 and 2003. They reported an average rate of tax credits attached to dividends of $77 \%$, for firms that paid dividends with tax credits. This compares to over $96 \%$ for the sample of all Australian firms between 2004 and 2015 used in this study, which excludes financial and real estate institutions. ${ }^{24}$ Further, like Amiran et al. (2016), Ikin and Tran (2013) made no distinction between firms not paying dividends and those paying dividends without tax credits. Greater insights are to be gained by examining the differences between these groups, rather than excluding them. Critically, it is the existence of these groupings of firms in Australia that provides an ideal setting to evaluate and test assumptions regarding 'imputation effects'.

While Wilkinson et al. (2001) examined the New Zealand imputation regime, they suffer from similar issues to Ikin and Tran (2013) and Amiran et al. (2015). They used a small, possibly unrepresentative sample, and a changes analysis involving a period very soon after the introduction of dividend imputation in New Zealand, and during one of the most far-

\footnotetext{
${ }^{23}$ For instance, eliminating the ability to "stream" tax credits to different classes of shareholders, may have increased the incentives for tax avoidance in order to compensate non-resident shareholders, while the refund of tax credits to resident shareholders who have no tax liability to offset, may have the opposite effect.

${ }^{24}$ The difference between the average tax credit percentages is possibly due to the different samples of firms in each study or to the non-refundable nature of tax credits during part of this period which may have downwardly biased the demand for tax credits, even from some domestic investors, including superannuation funds.
} 
reaching financial reform agendas in the developed world (Reserve Bank of NZ, 1996). Their measure of tax avoidance was based on the tax expense rather than the cash tax paid, despite the New Zealand system linking tax credits to the amount of tax actually paid. However, Wilkinson et al. (2001) acknowledged the limitations of their research and the weak support it provided for their hypotheses, and called for future research into this relationship using larger samples and in other jurisdictions with imputation. So far, no other research appears to have taken up that challenge. This paper responds to their call by attempting to address these issues.

While Wilkinson et al. (2001) investigated the differential effects of imputation on dividend clienteles, neither Ikin and Tran (2013) nor Amiran et al. (2016), considered the clientele effects on the incentives for tax avoidance. They both appear to assume homogeneity in the costs and benefits of corporate tax avoidance across firms. However, the changes to imputation in Australian during the late 1990's and early 2000's further entrenched the differential tax incentives facing various groups of firms and investors. Hence, this paper exploits the impact of dividend imputation on groups of firms that face different incentives for tax avoidance. Additionally, this paper considers whether managers engaging in tax avoidance do so in the best interests of their shareholders, by examining the role of corporate governance factors.

If dividend imputation alters the balance between the costs and benefits of tax avoidance, then theoretically, imputation provides the same level of benefits as tax avoidance without incurring the associated costs. Amongst the benefits of tax avoidance are increased cash flows, increased liquidity, and higher after-tax profits (Saveedra, 2013). Imputation provides a benefit equivalent to these increased cash flows through the distribution of tax credits. Imputation also removes the benefits of the debt tax shield, thereby improving liquidity 
through the use of increased equity finance (Schulman et al., 1996; Twite, 2001). The focus for firms that pay dividends with tax credits attached, moves from after-tax profits, in a classical dividend taxation system, to pre-tax profits (Bellamy,1994). Hence, dividend imputation is expected to provide similar benefits to tax avoidance without incurring the associated legal and transaction costs, or the risk of penalties and reputational damage. Thus, it is interesting that some firms engage in tax avoidance when dividend imputation is a viable alternative. Based on the intuition that dividend imputation mitigates the incentives for tax avoidance, and the evidence from prior research, it is hypothesised that:

H1: Firms paying dividends with tax credits attached undertake less tax avoidance than firms not paying dividends, or paying dividends without tax credits attached.

Confirmation of the above hypothesis would be an indication that there is a corporate response to Australian dividend imputation in the form of changed tax behaviour as some firms pay dividends with tax credits attached and thus limiting the need and incentive for tax avoidance without any loss in shareholder wealth. However, further theoretical discourse and propositions are necessary to ascertain whether this effect remains uniform across all firms, and therefore, if dividend imputation in Australia completely eliminates the benefits of tax avoidance so that managers do not pursue tax avoidance strategies.

\section{The Impact of Corporate Governance on Tax Avoidance and Imputation}

While the relevant literature has purportedly found a negative association between dividend imputation and corporate tax avoidance (Ikin and Tran, 2013; Amiran et al. 2016), it makes unsubstantiated assumptions as to what management should pursue in the best interests of shareholders. That is, in an imputation environment, managers in all firms will not engage in tax avoidance as it is ineffective in increasing shareholders' wealth (Lasfer, 1996; Amiran et 
al., 2016). This is likely to be correct only if there is homogeneity across the costs and benefits of corporate tax avoidance, and therefore, a uniform association between imputation and corporate tax avoidance. In this case the corporate governance role of monitoring in all firms would be to ensure higher tax payments and therefore an absence of tax avoidance. ${ }^{25}$ However, if the costs and benefits of corporate tax avoidance are heterogeneous, or the benefits of imputation do not completely mitigate the same benefits available through tax avoidance, there may be variation in the level of corporate tax avoidance across firms. This suggests a more diverse and less certain overall monitoring role for corporate governance in ensuring a firm's tax strategies are in the best interests of its shareholders. For example, for firms that have a clientele of mainly domestic investors, who prefer all earnings be distributed with full tax credits, the impact of imputation on the costs and benefits of tax avoidance would be significant. Conversely, for firms that have a clientele that either cannot derive any value from tax credits, or can still gain a greater tax advantage through capital gains taxes, the impact of imputation on the costs and benefits of corporate tax avoidance are minimal. There are likely other factors that also impact the costs and benefits of corporate tax avoidance across firms differentially. ${ }^{26}$ Hence, to examine assumptions in the extant literature as to management pursuits of tax avoidance, and its benefits to shareholders in an imputation setting, this paper considers whether corporate governance, by way of monitoring, impacts tax avoidance directly, and whether this is conditioned by the impact of dividend imputation on the costs and benefits of corporate tax avoidance.

\footnotetext{
${ }^{25}$ Another way to look at this is to assume that the benefits of imputation are complete and therefore there is no need and opportunity whatsoever to pursue a tax avoidance strategy by management which in fact will decrease shareholders wealth. This is possible in an extreme case where paying dividends with full tax credits puts a floor (presumably the statutory corporate tax rate) on the payment of tax and therefore completely eliminates any tax avoidance for all firms. In this case the role of monitoring would be ensure that no tax avoidance is pursued by management.

26 These factors are outside the imputation system and beyond the scope of this study.
} 
There are a number of corporate governance factors that have been found to impact the alignment of the interests of managers with those of shareholders, such as board independence and expertise, executive compensation and incentives, and ownership concentration and structure. There is extensive literature that identifies board independence as the most important factor, particularly in respect to tax avoidance (Pfeffer and Salancik 1978; Mace, 1986; Finkelstein and Mooney, 2003; Adams and Ferreira 2007; Hermalin and Weisbach 1988; Pfeffer and Salancik 1978; Armstrong et al., 2010; Lanis and Richardson; 2011; 2016). Therefore, this paper focuses on board independence when assessing the impact of governance by way of monitoring tax avoidance strategies. This paper extends the extant literature by examining this relation in both an imputation and a classical dividend taxation settings.

\section{The Monitoring Role of Outside Directors}

The effectiveness of the board of directors ${ }^{27}$ in monitoring the management of a firm is considered a function of the combination of inside and outside directors serving on the board (Fama 1980; Fama and Jensen, 1983). Outside directors are appointed in the interests of shareholders (Rosenstein and Wyatt, 1990) and depending on their knowledge-base and experience, outside directors on the board can have different functions (Coles et al. 2008). While knowledge and experience brought to a firm by outside directors can be used to counsel management about a firm's strategic direction (Adams and Ferreira, 2007), outside directors primarily provide independent monitoring of top management on behalf of shareholders (Fama and Jensen, 1983; Anderson and Reeb, 2004; Dahya and McConnell, 2005). Relevant literature also suggests that the unbiased monitoring provided by outside

\footnotetext{
${ }^{27}$ The board of directors is a market-induced, low-cost mechanism for the internal transfer of control of a firm from its shareholders to management (Fama \& Jensen 1983). It has an important role advising and monitoring senior management (Adams \& Ferreira 2007; Armstrong et al. 2010; Finkelstein \& Mooney 2003; Mace 1979).
} 
directors, to both the board and to managers, improves corporate decisions-making quality and protects shareholders' interests. (e.g. Anderson \& Reeb 2004; Dahya \& McConnell 2005). Hence, outside directors act as monitors of firm tax strategies, ensuring that the strategies pursued by management are in the best interests of shareholders (Lanis and Richardson; 2011; 2016).

\section{Outside Directors and Tax Avoidance in General}

Relevant literature on the impact of outside directors as monitors on tax avoidance provides competing theories and mixed results. For instance, Khurana \& Moser (2013) suggested that within an agency theory framework tax aggressiveness is value maximizing and an activity for achieving a transfer of wealth from the government to shareholders. Hence, it is in the best interests of shareholders and should be pursued by management. However, results in the literature are equivocal, as for instance Minnick \& Noga (2010) evaluated the impact of outside directors on corporate tax aggressiveness and found that governance factors, including board independence, were not significantly associated with either book or cash taxes. However, they claimed that the uncertainty involved in tax planning does not produce immediate benefits to the firm and is therefore a long-term investment. Using a long-term perspective to determine the lasting effects of corporate governance on investment in tax management, they found that investment in tax planning is positively related to higher shareholder returns over longer horizons.

Conversely, an Australian study by Lanis and Richardson (2011) found evidence that a higher proportion of outside members on the board of directors was associated with lower levels of tax aggressiveness. However, they were not concerned with dividend imputation and this was considered without controls for firms paying dividends with tax credits. Further, their study was based on a small and restricted sample of 16 firms that had first been described in official 
announcements in terms that suggested they had been tax aggressive, and second had received an amended tax assessment from the tax authorities over a five-year period. Hence, their sample was restricted to firms at the more aggressive end of the tax minimisation continuum, and this might not be representative of Australian publicly-listed firms in general. Other studies have also produced mixed results regarding the association between board independence and tax aggressiveness (e.g., Rego and Wilson, 2012; Robinson et al. 2012). Notably, the effects of board independence do not appear to be uniform across firms (Armstrong et al. 2015). Therefore, the literature provides empirical evidence that outside directors are associated with tax avoidance, or at least have a marginal effect on tax avoidance at the extremes, but the results seem inconsistent with respect to the direction of the association.

A potential contributor to this tension and the diverse results is heterogeneity of the costs and benefits of corporate tax avoidance across firms, as this potentially provides different results depending on the setting, cancel out results that do not control for this, or create erroneous results that are anomalous with theory. To the extent that dividend imputation is a prominent cause of differences in the costs and benefits of corporate tax avoidance, this may confound any association between outside directors and corporate tax avoidance. Further, the effect of dividend imputation in Australia is easily identifiable and measurable which provides for a solid setting to control for the heterogeneity in the costs and benefits of corporate tax avoidance. Thus, an interesting question is whether, after controlling for the effects of dividend imputation, there is an association between outside directors and corporate tax avoidance, and critically, the direction of any association. If Lasfer (1996) and Amiran et al. (2016) are correct that in an imputation environment, management are likely not to engage in tax avoidance to maximise shareholder wealth, there is an expectation of a positive association between outside directors and tax avoidance. However, that is an extreme 
assumption based on the view that the costs and benefits of corporate tax avoidance are homogenous. Relaxing that view, and considering the more likely case $\mathrm{e}^{28}$ of heterogeneity of the costs and benefits, creates tension as to the direction of any association. This position is somewhat supported by the mixed empirical results in the extant tax avoidance literature. Hence, the following hypothesis with respect to the proportion of outside directors and tax avoidance is non-directional:

H2: There is an association between the proportion of outside directors on a board and the level of tax avoidance.

If the assumption holds that management in an imputation environment do not pursue aggressive tax strategies and this is in the best interests of shareholders, given that the costs and benefits of corporate tax avoidance are homogenous, there is an expectation of uniformity to be exhibited across all firms. However, if the costs and benefits of corporate tax avoidance are heterogeneous, a further question arises as to whether this changes the tax strategies that mangers should pursue, and therefore, also changes the outcomes that will result from outside directors' monitoring. For firms that are not paying dividends, or paying dividends with no tax credits, there is no impact of dividend imputation on the incentives for corporate tax avoidance. Those firms are essentially akin to their counterparts in a classical tax regime, and therefore present an ideal setting for examining the Lasfer (1996) and Amiran et al. (2016) assumption that management are likely to pursue tax avoidance in the best interests of shareholders, in a classical dividend tax environment. ${ }^{29}$ If tax avoidance is in the best interests of shareholders for firms in that situation, the presence of outside directors should increase the level of tax avoidance for those firms. Hence, in the following hypothesis

\footnotetext{
${ }^{28}$ This is likely given the discussion surrounding hypothesis 1 and in particular the rudimentary evidence that in Australia a large proportion of firms pay no tax credits, which has been linked to tax-induced dividend clientele effect.

29 This proposition would also be prefaced with the homogeneity of costs and benefits of corporate tax avoidance assumption but the likely causes of heterogeneity in a classical system are not as prevalent, and hard to identify and measure.
} 
there is an expectation of a positive association between the proportion of outside directors and tax avoidance for firms that do not distribute tax credits:

H3: Board independence is positively associated with the level of tax avoidance for firms that pay no dividends or dividends with no tax credits.

Again, if the costs and benefits of corporate tax avoidance are heterogeneous in general, for firms that pay dividends with tax credits, managers in all firms will not engage in tax avoidance as it is ineffective in increasing shareholders' wealth (Lasfer, 1996; Amiran et al., 2016). However, that proposition also assumes that firms paying dividends with tax credits have no further incentive to pursue any tax avoidance strategy whatsoever. That assumption is unlikely under conditions inherent in the Australian imputation setting which prevents firms from fully streaming tax payments as tax credits attached to dividends, ceteris paribus. A more plausible scenario is that imputation, as has been suggested throughout the theory section, reduces (but does not completely eliminate) incentives for firms that pay dividends with tax credits for pursuing tax avoidance strategies as there is no benefit (or potentially a cost) to their shareholders.

There is at least a limit on the level of tax avoidance available to firms that pay dividends with tax credits because they have to pay tax in order to be able to pass it on. However, given certain constraints (an obvious one is the corporate tax rate itself as firms cannot stream tax payments beyond that as tax credits) $)^{30}$ on the amount of tax paid that can be streamed as tax credits attached to dividends, firms could still pursue tax avoidance strategies, albeit only to a certain limit and with less aggressiveness than firms that pay no dividends or dividends with

\footnotetext{
${ }^{30}$ The number one constraint is the upper limit at which tax credits can be attached to dividends which is equal to the current corporate tax rate. While tax credits can be accrued from year to year, their value diminishes over time and large accrued balances can be difficult to distribute as tax credits can only be attached to dividends at the maximum corporate tax rate. Therefore, large accrued balances of tax credits may be wasted, particularly if there is not a corresponding large balance in the retained earnings account. Wasted tax credits are not in the shareholders best interests and therefore may create incentives for tax avoidance in order to reduce the balance of accrued tax credits.
} 
no tax credits. This has the effect of introducing significant tension with respect to the choice of which management's tax avoidance strategy would be in the best interest of shareholders.

Firms can accrue large imbalances between accrued tax credits and retained earnings that could then provide, albeit to a lower degree, incentives to avoid tax. A source of large tax credit balances in excess of retained earnings arises from reductions in the corporate tax rate. Firms can also accrue large balances of retained earnings, as well as a corresponding large balance of tax credits, often with plans for a future distribution. However, if the corporate tax rate is reduced, retained earnings will not be sufficient to distribute all the accrued tax credits, as the maximum rate that tax credits can be attached to dividends is at the current tax rate. For example, if tax credits were accrued at $30 \%$ and the tax rate was subsequently reduced to $25 \%$, then $5 \%$ of the accrued tax credits would be wasted as now they can only be distributed at the maximum rate of $25 \%$. Prior to 2002 , profits were quarantined into categories for different tax rates, and when profits were distributed, it was on a first-in, first-out basis. However, subsequent to 2002, tax credits have accrued on a 'cash taxes paid' basis with no requirement for quarantining. While there have been no general reductions in the corporate tax rate since the 2002 reform, legislation passed in 2016 started a graduated reduction in the corporate tax rate from $30 \%$ to $25 \%$ for small, then medium firms, with an expectation that it will eventually flow through to large firms as well. The effect of the tax rate reduction on accrued tax credit balances has already produced some resistance to the reduction in corporate tax rates, particularly from shareholders who gain most value from dividends and the corresponding tax credits (Newnham, 2017).

In order to further evaluate the impact of outside directors as monitors on the tax avoidance of firms that pay dividends with tax credits and to test the implicit assumption expounded in Amiran et al. (2016) that dividend imputation completely eliminates the incentive for corporate tax avoidance, and therefore management should not pursue tax avoidance, the 
following hypothesis arises. It is expressed in a non-directional form because the extant constraints introduce a significant amount of tension with respect to the direction of any association between the proportion of outside directors and the level of tax avoidance for firms that pay dividends with tax credits.

H4: Board independence is associated with the level of tax avoidance for firms that pay dividends with tax credits.

\section{Research Design}

This paper is concerned with evaluating differences in the level of tax avoidance between firms paying dividends with tax credits, those paying dividends without tax credits, and those not paying dividends $\left(H_{1}\right)$, and also with the impact of board independence on those differences $\left(\mathrm{H}_{2}, \mathrm{H}_{3}\right.$ and $\left.\mathrm{H}_{4}\right)$. To test these hypotheses, the following baseline regression model is estimated:

CashETR $_{i t}=\propto_{0}+\propto_{1}$ DivTC $_{i t}+\propto_{2}$ DivNTC $_{i t}+\propto_{3}$ Outside $\%_{i t}+\propto_{4}$ Outside $\%_{i t} *$

$$
\operatorname{DivTC}_{i t}+\sum_{\gamma=5}^{k} \propto_{y} \text { Controls }_{i t}+\sum_{k+1}^{j} \propto_{k} \text { Indust }_{i t}+\sum_{j+1}^{l} \propto_{j} \text { Year }_{i}+\varepsilon_{i t}
$$

Where:

CashETR $_{i t}=$ Cash effective tax rate;

$\operatorname{DivTC}_{i t}=$ indicator variable equal to 1 if firm $i$ paid dividends with tax credits attached in year $t$, otherwise 0 ;

$\operatorname{DivNTC}_{i t}=$ indicator variable equal to 1 if firm $i$ paid dividends without tax credits attached in year $t$, otherwise 0 ;

Outside $\%_{\text {it }}=$ percentage of outside directors on the board of firm $i$ in year $t$;

Controlsit $=\mathrm{a}$ series of variables that have been shown to impact corporate tax avoidance; 
Industit $=$ indicator variable equal to 1 if firm $i$ has a specified 2-digit industry code in year $t$

Year $_{i}=$ indicator variable equal to 1 if firm $i$ has data in the specified year.

Equation (1) is estimated using an ordinary least squares regression on the pooled crosssection of firms, with year and industry fixed effects. For profit making firms, there is a reasonable presumption that, in the absence of tax avoidance, firms face an obligation to make corporate tax payments, and this potentially offers tax avoidance incentives.

\section{Tax Avoidance Measure - CashETR}

As tax avoidance cannot be observed directly, all measures of tax avoidance may be subject to error and have limitations (Hanlon and Heitzman, 2010; Lisowsky et al., 2013). ETR's have commonly been identified in the literature as the most useful measures for capturing and comparing the tax burden of firms and industries (Fullerton, 1984; Dyreng, Hanlon, and Maydew, 2008). ${ }^{31}$ Although the literature has used different measures of tax in the numerator, and different measures of income or cash flow in the denominator to calculate ETR's, ETR's remain widely used because: they capture a broad range of tax avoidance activities; they confirm potential levels of tax avoidance; and they provide a ranking of firms along the continuum of tax minimization activities (Dyreng, et al., 2010; Hanlon and Heitzman, $2010) .^{32}$

The specific measure of tax avoidance adopted here has been labelled the cash effective tax rate (CashETR). This measure was developed by Chen, Chen, Cheng, and Shevlin (2010) where tax paid from the Statement of Cash Flows is used in the numerator and income before taxes in the denominator. It has the benefit of capturing a broad range of tax planning

\footnotetext{
${ }^{31}$ In prior research, there have been different measures of tax used in the numerator, and for measures of income or cash flow used in the denominator. These choices are typically influenced by the particular research question.

32 This is consistent with the research definition in Footnote 8.
} 
activities that can have either certain or uncertain outcomes (Badertscher, Katz, and Rego, $2013),{ }^{33}$ it is not affected by changes in accounting estimates such as the valuation allowance or tax contingency reserve (Dyreng et al., 2008), and it is the variable of interest in a majority of empirical research into corporate tax avoidance (Blouin, 2014). Persuasively, evaluating tax avoidance on this basis is consistent with the process that generates imputation tax credits - cash taxes paid. Accordingly, the CashETR is calculated as:

$$
\operatorname{CashETR}_{i t}=\frac{\text { Tax Paid }_{i t}}{\text { Pre }- \text { tax } \text { Income }_{i t}}
$$

\section{Explanatory Variables}

Equation (1) addresses the first concern in this paper, which is whether dividend imputation impacts corporate tax avoidance. Variations in corporate tax avoidance for firms paying dividends with or without tax credits are assessed with indicator variables. It is appropriate to designate DivTC, which specifies firms that paid dividends with tax credits attached in the current period, as an indicator variable because during the period from 1996 to $2015,96 \%$ of firms attached tax credits at a rate of $100 \%$. If firms paying dividends with tax credits avoid less tax than other firms $\left(H_{1}\right)$, the coefficient on this variable from estimating Equation (1) will be negative. The indicator variable DivNTC is used to identify firms that pay dividends without tax credits. Relative to firms not paying dividends, dividend imputation is not expected to impact the costs and benefits of tax avoidance for these firms and the coefficient on this variable is not expected to be significant. However, the financial requirements for paying dividends may impose constraints on tax avoidance, and this may result in less tax

\footnotetext{
33 The CashETR also has limitations, as it can potentially capture outcomes that are not associated with tax aggressiveness, such as large depreciation deductions (Khurana and Moser, 2012), investments in municipal bonds (Kim et al., 2011; Khurana and Moser, 2012), and research and development tax credits (Treasury, 2015). It is also affected by the exercise of stock options (Blouin, 2014).
} 
avoidance and potentially, a negative coefficient. This would be more appropriately labelled a dividend effect rather than a dividend imputation effect.

The other explanatory variable is Outside\% which is calculated as the percentage of outside directors on the board. In Equation (1), this variable captures the impact of outside directors on the CashETR generally $\left(\mathrm{H}_{2}\right)$. To further explore this association, Outside\% is also interacted with DivTC to identify the differential impact of outside directors in firms that pay dividends with tax credits. If outside directors are associated with corporate tax avoidance for firms not paying dividends or paying dividends without tax credits $\left(H_{3}\right)$ we expect a negative coefficient on Outside\%. The difference in the association between outside directors and corporate tax aggressiveness for firms paying dividends with tax credits $\left(\mathrm{H}_{4}\right)$ is captured by the interaction.

\section{Control Variables}

There are an extensive range of variables that have been used in the literature to control for known determinants of variation in tax avoidance. Firm size (Size) is commonly included as a control for tax avoidance and this is likely relevant due to there being significant transaction costs in establishing the necessary structures (Zimmerman, 1983; Omer, Molloy, and Ziebart, 1993) and this impacts the demand for corporate tax avoidance. However, there is conflicting evidence as to the direction of the effect (e.g. Stickney and McGee, 1982; Zimmerman, 1983). This may be a consequence of increasing political costs associated with firm size, as the tax affairs of larger firms receive greater scrutiny in the media and from tax authorities potentially limiting the benefits available from corporate tax avoidance (Zimmerman, 1983). Size is measured by the natural log of total assets. The demand for tax aggressive strategies is also likely influenced by profitability as there are clearly larger benefits from corporate tax avoidance if there is potentially greater tax that would otherwise be payable. Accordingly, 
return on assets $(R O A)$ is also included as a control variable and is measured as pre-tax income divided by total assets.

Early tax research found that the lowest ETR's are associated with high leverage (LEV) and high levels of capital intensity (CAPINT) (Stickney and McGee, 1982; Omer et al., 1993). Capital intensity identifies a constraint on shifting operations and profits, and $L E V$ recognizes the tax shelter provided by debt and the use of debt in profit shifting. Intangible assets (INTAN) are measured as the ratio of intangible assets to total assets, although a challenge with this measure is the often limited recognition that is assumed to be the real economic value of intangible assets. Researchers have also considered research and development costs (RDINT), which may have concessional tax treatment, and can be indicative of intangible assets which can facilitate profit shifting. Finally, TotalAccruals is included to control for the effect of earnings management on the denominator of the CashETR, TotalAccruals is calculated as net increase in cash held divided by net income.

\section{Sample Selection and Description}

Panel A of Table 1 describes the initial sample selection process for the baseline tests. Sample firms to test the association between tax avoidance and dividend $\left(H_{1}\right)$, and for the impact of board independence on corporate tax avoidance $\left(\mathrm{H}_{2}, \mathrm{H}_{3}\right.$ and $\left.\mathrm{H}_{5}\right)$, are taken from the Aspect Huntley database. Initially all firms listed on the Australian Stock Exchange (ASX) during financial-years 2004 to 2015 are included. This period is selected due to limited availability of some data items for outside directors (Outside\%) in the firms covered on the database before 2004. The period is also selected as it is subsequent to a period of major changes to the Australian imputation, which amongst other changes, extended the benefits of imputation to a greater proportion of shareholders, while also closing down loopholes for others who did not qualify to benefit from tax credits. There have been no major changes to 
dividend imputation in Australia during the sample period selected or any change to the corporate tax rate producing a period of stability to test the imputation effects. There are 21,384 firm-year observations listed on the ASX during this period. Firm-year observations are deleted from the sample: for any years they report losses, as firms making a loss will be less likely to pay tax or pay dividends $(12,422) ;{ }^{34}$ if they are in the financial services and utilities industries because they are subject to different and more stringent regulations that are likely to affect their tax avoidance measures $(2,157)$; if there are firm-years with missing data (914); or with missing outside director data $(1,162)$. This leaves a final sample of 4,729 firmyears.

[insert Table 1 near here]

Consistent prior research, CashETR, CAPINT, RDINT and INTAN are winsorised between the values of zero and one, and LEV is winsorised at the $1 \%$ and $99 \%$ values, in order to reduce the influence of extreme observations (Gupta and Newberry, 1997; Frank, Lynch, and Rego, 2009; Armstrong et al., 2012). ${ }^{35}$ Panel C of Table 1 demonstrates that industry distribution classified according to global industry classification system (GICS) of sample firms are drawn across a reasonably balanced cross-section of industries indicating that there is no significant degree of industry bias in the sample. Similarly, Panel D of Table 1 demonstrates that the distribution of firm-years across the sample remains reasonably distributed indicating that there is no significant degree of bias occurring from any sample year.

\footnotetext{
${ }^{34}$ A significant number of firms listed on the Australian Stock Exchange are small mining exploration companies, which are individually economically insignificant. These firms are loss making in most years.

${ }^{35}$ It is possible for a firm to have cash taxes paid greater than the measure of book income for the year, thereby producing a negative CashETR. However, those situations are outside normal business parameters and are usually related to the reversal of a previous transaction, such as a successful challenge by the tax authorities to a previous tax position taken by the firm. It is also possible for firms to have an amount for cash taxes paid while reporting a loss in the same period, or to receive a tax refund while reporting a profit. However, these circumstances produce negative measures of tax avoidance which are outside the normal bounds for profitable firms and can be difficult to interpret (Gupta and Newberry, 1997).
} 
Descriptive statistics for the sample of firm-years are presented in Table 2. CashETR for the full sample in Panel A has a mean (median) value of 0.202 (0.158) indicating that the sample is skewed towards higher CashETR's, and that on average firms reduce their CashETR's by ten percentage points from the $30 \%$ corporate tax rate. This demonstrates tax avoidance strategies are being employed amongst the sample firms. Dividends are paid in $68.4 \%$ of firm-year observations which is in line with other research reporting Australian data (Pattenden and Twite, 2008; Hail, Tahoun \& Wang, 2014). Dividends with tax credits are paid in $58.5 \%$ of all firm-years, or $85.5 \%$ of observations where dividends have been paid. This suggests considerable variation between the groups of firms not paying dividends, those paying dividends without tax credits, and those that pay dividends with tax credits, confirming the decision to evaluate the impact of dividend imputation on corporate tax avoidance. Outside directors constitute $54.9 \%$ of the membership of boards represented in this sample.

\section{[insert Table 2 near here]}

In Panel $\mathrm{C}$ of Table 2 the sample is split into observations where (i) dividends were not paid (NoDiv), (ii) those where dividends were paid without tax credits (DivNTC), and (iii) those where dividends were paid with tax credits (DivTC). The mean for CashETR is considerably lower for observations where dividends were not paid or tax credits were not distributed. The mean CashETR for DivTC observations is approximately sixteen percentage points above the mean for other observations. This provides initial support for the first hypothesis $\left(H_{1}\right)$, that firms paying dividends with tax credits attached undertake less tax avoidance than firms not paying dividends, or paying dividends without tax credits attached.

Correlations between all variables used in the models are presented in Table 3, with the full sample in Panel A, and the foreign ownership sample in Panel B. In Panel A, there is a strong 
correlation between CashETR and DivTC, and a negative correlation with firms that do not pay dividends (NoDiv) or distribute tax credits (DivNTC). There is also a moderate positive correlation between DivTC and a number of the control variables.

[insert Table 3 near here]

\section{Results}

Results from estimating Equation (1) are presented in Table 4. The difference in tax avoidance between firms paying dividends with tax credits and those not paying dividends is captured by the coefficient on DivTC. For firms paying dividends without tax credits, it is captured by the coefficient on DivNTC. The impact of outside directors (Outside\%) on tax avoidance $\left(H_{1}\right)$ and the interactive term between Outside\% and DivTC assess whether outside directors have a disproportionate impact on firms that engage in dividend imputation $\left(\mathrm{H}_{3}\right.$ and $\left.H_{4}\right)$.

[insert Table 4 near here]

In the baseline model (Column 1), the coefficient on DivTC is positive and significant $\left(\alpha_{1}=\right.$ $0.123, \mathrm{t}$-stat $=13.163)$, while the coefficient on DivNTC is negative but not significant $\left(\alpha_{2}=-\right.$ 0.022 , $\mathrm{t}$-stat $=-1.849)$. This indicates that firms paying dividends with tax credits engage in less tax avoidance than firms that either do not pay dividends or pay dividends without tax credits. The difference between firms not paying dividends and those paying dividends without tax credits $\left(\alpha_{2}\right)$ demonstrates that these differences are a consequence of paying dividends (i.e., a dividend effect), and the difference between firms paying dividends with and without tax credits confirms a dividend imputation effect. Critically, this result demonstrates ETR's being 12.3 percentage points higher for firm-years where dividends are paid with tax credits compared to those that did not pay dividends, and $14.4 \%$ higher than firm-years where dividends are paid without tax credits. The results are strongly supportive of 
an economically significant reduction in corporate tax avoidance as an outcome from dividend imputation $\left(H_{1}\right)$.

A further issue that is considered is whether this result is impacted by corporate governance and board independence in particular. To evaluate this proposition, the proportion of outside directors on a firm's board (Outside\%) is included as a control measure, and the results of this analysis are reported in Column (2) of Table 4. The coefficient on Outside\% indicates that there is a negative and significant association between the presence of outside directors and lower cash ETR's $\left(\alpha_{3}=-0.099\right.$, t-stat $\left.=-3.931\right)$. Notably, the inclusion of Outside\% does not change the tenor of the other results. However, caution is suggested as this might be attributable to firms that are not paying dividends or paying dividends without tax credits, as dividend imputation does not impact the costs and benefits of corporate tax avoidance for these firms.

To isolate the effect of outside directors on the level of tax avoidance for firms paying dividends with tax credits, outside directors (Outside\%) and an interaction term between outside directors and firms paying dividends with tax credits (Outside\%*DivTC) is included in the baseline model. The results are presented in Column (3) of Table 4. It is notable that this coefficient on DivTC has increased ( $\alpha_{1}=0.147$, t-stat $=5.432$ ), strengthening support for $\mathrm{H}_{1}$. There is a negative association between outside directors and cash ETR's $\left(\alpha_{3}=-0.076\right.$, tstat $=-2.038$ ). This suggests that where firm-years where dividends are not paid, or paying dividends without tax credits, there is a higher level of tax avoidance in the presence of stronger governance and monitoring $\left(H_{3}\right)$. The coefficient on the interaction term between outside directors and firms paying dividends with tax credits is not significant $\left(\alpha_{4}=-0.044\right.$, tstat $=-0.911)$. Hence, there is evidence that after controls for the payment of dividends with tax credits there is no difference in the impact of outside directors on tax avoidance between 
those paying dividends with tax credits and those paying dividends without tax credits or not paying dividends. Further, the association between corporate tax avoidance and governance for these firms (i.e., $\left.\alpha_{3}+\alpha_{4}\right)$ is significant $\left(H_{4}\right)$. This result suggests that while dividend imputation mitigates the incentives for tax avoidance, there remain differences in the costs and benefits of corporate tax avoidance due to the constraints of imputation and hence, there still remains some incentive to avoid tax when paying dividends with tax credits attached. However, an evaluation of this outcome is beyond the scope of this paper which is primarily concerned with the impact of dividend imputation on corporate tax avoidance.

The coefficients on the control variables are generally consistent with expectations. Size is positive and statistically significant in all models but the economic significance is low $\left(\alpha_{5}=\right.$ 0.009 to 0.012 , $\mathrm{t}$-stat $=5.024$ to 6.004$)$. Of the other control variables, only capital intensity (CAPINT) and intangibles (INTAN) are statistically significant, with both being positive.

\section{Additional analysis, sensitivities and robustness checks}

There is a growing literature suggesting the costs and benefits of tax avoidance may be heterogeneous across firms for reasons other than imputation (Austin and Wilson, 2017; Edwards et al., 2016; Guenther et al., 2016; Hanlon \& Slemrod, 2009). For example, Hanlon and Slemrod (2009) found that firms in retail industries were more sensitive to reputational concerns arising from alleged involvement in tax shelter activity. Dyreng et al. (2014) also found that firms reliant on consumer discretionary expenditure were more sensitive to disclosures that might impact their reputation. Dividend imputation in Australia provides an ideal setting to examine the differential costs of tax avoidance across different groups of firms. If firms in certain industries are more sensitive to reputational costs associated with tax avoidance, there are strong incentives for firms in those industries to avail themselves to the advantages of imputation. Hence, there should be a higher probability of firms in those 
industries paying dividends with tax credits attached. Therefore, the following model is used to test this:

$$
\operatorname{DivTC}_{i t}=\delta_{0}+\sum_{k=1}^{6} \delta_{k} \text { Industry }_{i t}+\sum_{k+1}^{j} \delta_{j} \text { Controls }_{i t}+\varepsilon_{i t}
$$

Where:

$\operatorname{DivTC}_{i t}=1$ if firm $i$ pays a dividend with a tax credit in year $t$, else 0.

Industryit $=1$ if firm $i$ is in the specified 2-digit GICS code in year $t$.

Controls $_{i t}=$ the array of controls used in Equation (1).

The model is run on a sub-sample of firm-years when dividends were paid. The model is estimated using a probit regression model with year fixed effects on the pooled, cross-section of firm-years. The results are presented in Table 5. The coefficients on all industries are statistically significant, with a negative association with paying dividends with tax credits. This indicates that firms engaging in imputation are not clustered in any particular industry as suggested by prior literature (Hanlon and Slemrod, 2009; Dyreng et al., 2015) and therefore, the costs associated with tax avoidance appear to be homogenous across dividend paying firms, regardless of whether they distribute tax credits. This also implicitly confirms the point made in an earlier section that causes, other than imputation, of heterogeneity of the costs and benefits of tax avoidance are not as prevalent, hard to identify and measure, making Australia an ideal setting for testing assumptions with respect to the heterogeneity/homogeneity of the costs and benefits of tax avoidance.

Further insights into the impact of dividend imputation on corporate tax avoidance may be gained from investigating the ownership structures between firms that distribute tax credits and others. As non-resident shareholders are generally unable to benefit from the tax credits, the benefits of corporate tax avoidance are not ameliorated by dividend imputation for these shareholders. This suggests that firms with high levels of foreign ownership are more likely 
to engage in corporate tax avoidance in order to maximise shareholders benefits. As avoiding tax and distributing tax credits are mutually exclusive pursuits, these firms are less likely to pay dividends with tax credits attached. Subsequently, the following model is estimated to evaluate whether firms paying dividends with tax credits have lower foreign share ownership.

$$
\text { Foreign }_{i t}=\delta_{0}+\delta_{1} \text { DivTC }_{i t}+\sum_{\gamma=2}^{k} \delta_{y} \text { Controls }_{i t}+\sum_{k+1}^{j} \delta_{k} \text { Indust }_{i t}+\epsilon_{i t}
$$

Where:

Foreign $\%$ it $=$ percentage of shares held by foreign investors;

DivTC $_{i t}=$ indicator variable equal to 1 if firm $i$ paid dividends with tax credits attached in year $t$, otherwise 0 ;

Controlsit $=\mathrm{a}$ series of variables that have been shown to impact corporate tax avoidance;

Indust $_{i t}=$ indicator variable equal to 1 if firm $i$ has a specified 2-digit industry code in year $t$

The measure of non-resident share ownership (Foreignit) is the percentage of shares held by foreign investors. To the extent that non-resident shareholders are unable to benefit from the tax credits attached to dividends, it is expected that these firms would be less likely to pay corporate taxes and hence, dividends with tax credits. Accordingly, the coefficient on DivTCit is expected to be negative.

Due to limited data availability, the sample employed to test the association between foreign ownership and the payment of dividends with tax credits is limited to the 2015 financial year. The sample selection process is outlined in Panel B of Table 1. Foreign ownership data is obtained from the IBIS World database using the ownership percentage and geographical location of the Top 20 shareholders for each firm, as disclosed in the notes to their financial statements. This will potentially understate the level of foreign ownership of Australian 
companies, as some shareholders are listed through nominees in Australia, and it excludes foreign shareholders not in the Top 20. The understatement of foreign ownership will likely create bias against finding a significant result. Ownership data is only available for 326 firms. The sample is reduced for firms where losses are reported (78), firms in the financial services and utilities industries (51), and firms with missing data (1), leaving a sample of 196 firms.

Descriptive statistics for the foreign ownership sample are displayed in Panel B of Table 2. The level of foreign ownership for the sample is only $7.6 \%$. This is much lower than the level reported in prior research (Wilkinson et al., 2001) or reported by government sources (Department of Foreign Affairs and Trade, 2016) which both estimate the level of foreign ownership at closer to $30 \%$. This may be due to only using data for the Top 20 shareholders and their reported geographical location. However, the lower proportion creates a potential bias against finding a significant result for this test. In Panel $\mathrm{C}$ of Table 2, where the sample is divided into groups, the level of foreign ownership for DivTC observations (0.041) is considerably lower than for other observations $(0.160$ and 0.200$)$ indicating the likely presence of tax-induced dividend clienteles based on residency status.

Table 6 presents the results of testing whether an association exists between the payment of dividends with tax credits and foreign share ownership. The coefficient on DivTC is negative and significant $\left(\delta_{1}=-0.123\right.$, t-stat $\left.=-3.569\right)$, which indicates firm-year dividends paid with tax credits have lower foreign share ownership. Interestingly, the only other coefficient that is significant is CAPINT. This suggests there may be little else determining foreign investment. ${ }^{36}$ The model from Equation (2) has an adjusted R-squared of $13.7 \%$ indicating its explanatory power.

[insert Table 6 near here]

\footnotetext{
${ }^{36}$ Again, examining this point is beyond the scope of this paper.
} 
This analysis indicates that the payment of dividends with tax credits appears to be associated with firms where shareholders are able to obtain benefit from tax credits. Where shareholders are unable to gain any benefit from the tax credits, such as foreign shareholders, firms appear to engage in tax avoidance in order to provide additional benefits to their shareholders. This is consistent with dividend imputation reducing the incentives for tax avoidance and $H_{1}$.

Additional sensitivity tests to ensure the robustness of the reported results are also undertaken. The results are presented in Table 7. First, an indicator variable (PostGFC) is included in the model from Equation (1) to assess the impact of the Global Financial Crisis (GFC) in 2007 and 2008. PostGFC is set to one if the financial year was after 2008, and zero otherwise. PostGFC is also interacted with DivTC to estimate differential effects. The coefficient on PostGFC is positive and significant $(\alpha$ PostGFC $=0.051$, t-stat $=2.682)$, indicating that firms in general have reduced their levels of tax avoidance since the GFC. Critically, the interactive term is not significant, indicating that the reduction in tax avoidance is found across all firms-years. This also suggests that CETR (i.e. tax aggressiveness) is not endogenous with dividend payments.

In untabulated results, annual cross-sectional regressions for the baseline model from Equation (1) are also evaluated. A Wald test of the differences in the coefficients is used to assess the significance of the main results which may be overstated due to the use of a crosssectional research design. When Equation (1) is estimated annually, the coefficient on DivTC is negative and statistically significant in every year. The Wald test of difference in the coefficients for DivTC and DivNTC is positive and significant in both the pooled crosssection, and in all of the annual cross-section regressions. The results from this analysis are consistent with the results from our main regression. 
The two previous sensitivity tests provide limited evidence to support the independence of the main variables, they do not directly address concerns of endogeneity, reverse causality or selection bias. Therefore, a two-stage least squares (2SLS) regression was fitted with a wide range of possible instruments. However, all instrumental variables considered are found to be too weak to provide significant results in the first stage. ${ }^{37}$ Therefore, the 2 SLS could not be used to reliably address selection bias and propensity score matching is employed instead. Propensity score matching (PSM) seeks to alleviate concerns that the observed difference between two groups, such as DivTC and DivNTC, is due to the method of selection rather than the treatment effect. PSM uses a vector of observed variables to predict the probability that a particular observation will be in the treatment group. It uses those variables to match the high probability observations to other observations that have a low probability of experiencing the treatment, as a control group. The results from the PSM are presented in Table 8 . These results are bootstrapped and remain consistent with the results from our main regression.

The second test that is contemplated is a first differences analysis which relies on variation in the independent variables. However, the independent variables in Equation (1) are indicator variables and therefore, are unsuitable for use in first differences analysis; a Fama-MacBeth two-step regression is used instead. The Fama-MacBeth two-step regression controls for correlated residuals in the cross-section of observations and is used to correct for bias in the OLS standard errors. The results of the Fama-MacBeth regressions are presented in Table 9. These estimates remain consistent with our main results.

\footnotetext{
${ }^{37}$ For a discussion of the issues associated with the use of selection models, including two-stage least squares regressions; see Lennox, Francis and Wang (2012).
} 


\section{Conclusion}

The objective of this paper is to evaluate whether dividend imputation impacts corporate tax avoidance. Next, is to test the assumption of extant literature that in dividend imputation environments, managers in all firms will not engage in tax avoidance, as it is ineffective in increasing shareholders' wealth (Lasfer, 1996; Amiran et al., 2016). Specifically, testing if the costs and benefits of corporate tax avoidance, as implicitly assumed by Lasfer (1996) and Amiran et al. (2016) are homogenous in an imputation setting.

Rigorous theoretical analysis in this paper proposes $\left(H_{1}\right)$ that firms paying tax credits undertake less tax avoidance than those which do not. A significantly lower level of corporate tax avoidance for firms that are paying dividends with tax credits is found to be exhibited across sample firm-years. This is economically significant with firms paying dividends with tax credits attached having a cash ETR up to 16.9 percentage points higher than firms that pay dividends without tax credits, and up to 14.7 percentage points higher than firms that do not pay dividends. Therefore, dividend imputation alters the balance between the costs and benefits of tax avoidance by providing the same level of benefits as tax avoidance without incurring the associated costs. This confirms that there is a corporate response to Australian dividend imputation in the form of changed firm tax behaviour.

$H_{2}, H_{3}$ and $H_{4}$ specifically relate to the contention that the costs and benefits of tax avoidance are homogenous, thereby, as corporate tax avoidance increases the return to shareholders it would be in the best interest of shareholders of all firms in a classical tax regime and as corporate tax avoidance decreases the return to shareholders it would not be in the best interest of shareholders of all firms in an imputation regime (Lasfer, 1996; Amiran et al., 2016). In order to test these assumptions, the corporate governance role of monitoring is controlled for by way of outside directors. $\mathrm{H}_{2}$ proposes a non-directional association between 
outside directors and tax avoidance in Australia given the potential impact of the tax-induced dividend clientele effect. The results indicate a positive significant association exists between outside directors and tax avoidance, indicating that managers pursue higher levels of tax avoidance to maximize shareholders wealth in an imputation setting. This is consistent with $H_{1}$, and inconsistent with the Lasfer (1996) and Amiran et al. (2016). It suggests that the costs and benefits of tax avoidance are heterogeneous due to the tax-induced dividend clientele effect and that overall the management of firms in Australia still pursues tax avoidance. $H_{2}$ in the context of those firms that do not pay tax credits, proposes that management would pursue tax avoidance by way of a positive association between outside directors and tax avoidance in consistency with a classical tax system setting (Lasfer, 1996; Amiran et al., 2016). The results are consistent with $H_{2}$, therefore suggesting the Lasfer (1996) and Amiran et al. (2016) assumption with respect to management pursuing higher tax avoidance in a classical tax system is accepted.

The final hypothesis $\left(\mathrm{H}_{4}\right)$ proposes a non-directional association between outside directors and tax avoidance given the constraints on the ability of firms that pay dividends with tax credits to distribute all tax paid in the form of those tax credits. The results indicate that there is a positive association between outside directors and tax avoidance for those firms that pay dividends with tax credits. This is inconsistent with the Lasfer (1996) and Amiran et al. (2016) assumption with respect to management not engaging in tax avoidance in an imputation setting which further confirms $H_{1}$, albeit for reasons related to the inherent constraints built into the imputation system which prevents even those firms that pay dividends with tax credits to fully stream all the tax paid as tax credits. Thus, overall the results suggest that imputation, although reducing incentives, and therefore the possible level, for firms that pay dividends with tax credits with which to pursue aggressive tax strategies, does not completely eliminate that pursuit by firms in Australia. 
This paper contributes to both the contemporaneous public discourse on corporate tax avoidance and the extant literature, by extending the research examining the effectiveness of regulatory responses to corporate tax avoidance. It identifies the potential for dividend imputation to mitigate the incentives for firms to engage in tax avoidance strategies by better aligning shareholders' interests with those of the tax authorities (Bellamy 1994). This paper also contributes to the literature on dividend imputation and the value of tax credits, as well as the literature on the determinants of corporate dividend policy. It also contributes to the growing research into the heterogeneity of the costs associated with corporate tax avoidance, by for the first time utilising an ideal setting to observe these effects and at the same time addressing the inherent problems in the extant literature made through unsubstantiated assumptions.

A final contribution is made to the current policy debate both globally and in Australia, where a Treasury review of the Australian taxation system has made a direct reference to the abolition of dividend imputation (Treasury, 2015). On the one hand, Treasury conjectures that dividend imputation may encourage Australian firms to pay tax in Australia. On the other hand, it suggests imputation provides little net benefit to Australia. A potential reason for this tension is the paucity of rigorous empirical research in this area. Hence, this research contributes to this debate by demonstrating that because dividend imputation requires corporations to pay tax in order to be able to pass credits onto the shareholders, this places economically significant constrains on corporate tax avoidance.

While the results in this paper indicate a strong influence of dividend imputation on the level of tax avoidance, it is acknowledged that there are limitations with the data and methods employed and that further research is needed into the impacts of dividend imputation on corporate and investor decision making. The large cross-sectional variation in the tax 
avoidance proxies for the sample of firms that pay dividends with tax credits attached warrants further examination, particularly with regard to constraints on the ability of firms to distribute tax credits. A related anomaly is firms that pay both tax and dividends but do not distribute tax credits, potentially wasting the value of the tax payments. Further investigation in to the characteristics of these firms is warranted. The paucity of available ownership data makes inferences from the foreign ownership tests problematic beyond signalling an effect, with the size of any effect difficult to reliably quantify. The foreign ownership data only recognizes the largest shareholders, and some observations do not provide reliable geographical information.

There are other issues associated with dividend imputation that are beyond the scope of this paper that should also be pursued in future research. For example, dividend imputation may create incentives for firms to pay dividends, as opposed to re-investing retained profits. This has been identified as a possible distortion in the capital markets. However, the necessity for firms to raise capital for investment projects through the capital market has been identified as a disciplining mechanism, possibly protecting shareholders against unprofitable, "trophy" investments by managers. It is also possible that dividend imputation impacts foreign direct investment in Australia and Australian investors considering investing overseas. Finally, for firms paying dividends with tax credits there is still a large cross-sectional variation in their ETR's which can be investigated in future research. 


\section{Appendix A: Dividend Imputation in Australia}

In Australia, dividend imputation was introduced in 1987. It's designed to address the double taxation of company income when paid out as dividends, and is similar to integrated tax systems that were introduced in Italy, Germany and New Zealand, because it allows for the full amount of taxes paid on company profits to be distributed to shareholders as tax credits attached to dividends. The 2010 Henry Review of Taxation in Australia asserted that only New Zealand and Australia had imputation systems currently operating. ${ }^{38}$

Dividend imputation essentially passes the payment of corporate taxes as a benefit to shareholders. Hence, corporate taxes may therefore be considered "not really company tax but rather a collection of personal tax at the company level" (Officer 1994, p.4). ${ }^{39}$ Whilst tax credits that cannot be used to offset other income are fully refundable to individuals and qualifying superannuation funds, they cannot be redeemed by non-residents against their personal income tax liabilities in their home country. Legislation was introduced in Australia in 1997 to prevent the practice of non-resident owned firms "selling" their undistributed franking account balances (i.e. tax credits) to resident-owned firms through mergers and acquisitions. Hence, the dividend imputation favours Australian resident shareholders over non-residents. The level of benefits available are not uniform across all resident shareholders, because the marginal tax rate on each shareholders total personal income is heterogeneous. Hence, variations in the value attributed to the tax credits is dependent on the tax status of the individual shareholder.

\footnotetext{
38 There have been various forms of dividend imputation systems operating in many countries throughout the world, although many have now been abolished. However, Malta introduced a form of dividend imputation in 2007, and Mexico, Chile and Canada have full imputation systems (as at May 2014). Other countries such as United Kingdom and Korea have partial imputation systems. The U.K. had full imputation until 1997. Full or partial imputation systems have been abolished in Germany (abolished in 2001), France (2004), Finland (2005), Norway (2006), Spain (2006), Turkey (2002), Singapore (2003), and Malaysia (2008). [Source: OECD (2015)]. 39 This is comparable to a withholdings tax on wages paid to employees where tax is withheld when the dividends (wages) are paid and the shareholder (employee) claims the credit for the amount of tax already paid in Australia when they file their personal tax return.
} 
The dividend imputation can be seen in contrast to dividend taxes under a "classical" system. With a classical tax system corporate profits are taxed twice, first in the hands of the company at the corporate tax rate, and second, if distributed as dividends, in the hands of the shareholders at their personal tax rate. Therefore, that rate of tax on corporate profits is the corporate tax rate plus the investor's personal or dividend tax rate, and shareholders gain no benefit for tax paid at the corporate level.

However, using the Australian dividend imputation system, firms pay tax on profits at the corporate tax rate (currently $30 \%$ ) before the potential distribution of those profits to shareholders as dividends. Each firm maintains a "franking" account and tax credits accrue to the franking account for cash taxes paid to the Australian Tax Office. While tax credits can be accrued indefinitely, their value, as with money, decreases over time. There is also the difficulty of distributing them with future dividends unless tax is paid at below the statutory rate on future earnings. A tax credit, known as a franking credit, may be attached to dividends to reflect the tax already paid on that income at the corporate level. The "franking credit" is calculated as:

\section{Franking Credit $=$ Div $\times$ ctr $/(1-$ ctr $) \times$ Franking Percentage}

Where: Div $=$ dividend amount; and, $c t r=$ corporate tax rate

The Franking Percentage is decided by the firm based on available credits in their franking account and takes a value between 0 and 1 . Dividends with tax credits that have had tax paid at the full statutory tax rate on the underlying profit are known as fully, or $100 \%$, franked dividends. Partially franked dividends refer to dividends that have tax paid at less than the statutory tax rate. There is a maximum level franking credits that a company can attach to dividends. The maximum that can be distributed is $100 \%$ franked dividends $(30 \%$ of the 
grossed-up dividend amount under the current STR). It is best illustrated by the following formula:

Maximum franking amount $=$ Div $\times$ ctr $/(1-c t r)$

In the sample used in this research, the franking percentage was $100 \%$ in $96 \%$ of instances where dividends have been paid with tax credits attached, between 1996 and 2014. When shareholders (individual and corporate) who have received franked dividends file their tax returns, the cash dividends are "grossed up" by adding the amount of the franking credit. Tax is paid on the grossed up amount at the applicable tax rate and the resultant tax liability is then reduced by the amount of the franking credit with the balance being tax payable. Income from foreign operations is not taxable in Australia to the extent that tax has been paid to foreign tax authorities, and therefore, does not generate franking credits.

An example of the workings of the imputation system and its comparison with a classical system is outlined in Table A1. The illustration includes the following assumptions:

1. The corporate tax rate is $30 \%$ in all scenarios

2. The level of deductions used for tax avoidance is $50 \%$ of the Net Profit before Tax

3. The cost of the deduction for tax avoidance is $10 \%$ of the value attained.

4. All profits are distributed as dividends

5. Dividends are franked to the maximum amount possible

6. There is no opening balance to the franking account

7. The marginal tax rate is $35 \%$; the dividend tax rate is $15 \%$.

Table A1: Illustration of the Australian Dividend Imputation System

Imputation

$\underline{\text { Firm }}$

Operating profit

Less Cost of tax avoidance
(1)

No tax avoidance

(2)

Classic

$1,000,000 \quad 1,000,000$

$0 \quad 0$
(3)

Imputation With tax avoidance

$1,000,000 \quad 1,000,000$

$(50,000) \quad(50,000)$

(4)

Classic 
$(10 \%)$

Net Profit before Tax

Tax avoidance (50\%)

Taxable Income

Company tax rate

Tax Paid

Net Profit after Tax

\section{Dividends}

Dividend payout ratio

Cash dividends

Franking credits

Franking \%age

\begin{tabular}{|c|c|c|c|}
\hline $1,000,000$ & $1,000,000$ & 950,000 & 950,000 \\
\hline 0 & 0 & $(500,000)$ & $(500,000)$ \\
\hline $1,000,000$ & $1,000,000$ & 450,000 & 450,000 \\
\hline $30 \%$ & $30 \%$ & $30 \%$ & $30 \%$ \\
\hline$(300,000)$ & $(300,000)$ & $(135,000)$ & $(135,000)$ \\
\hline 700,000 & 700,000 & 815,000 & 815,000 \\
\hline
\end{tabular}

$\begin{array}{rrrr}100 \% & 100 \% & 100 \% & 100 \% \\ 700,000 & 700,000 & 815,000 & 815,000 \\ 300,000 & & 135,000 & \\ 100 \% & & 55 \% & \end{array}$

$\underline{\text { Shareholder }}$

\%age of Shares

Cash dividends

Franking credits

Dividend income (grossed-up) Marginal tax rate

Tax liability

Less Franking credits

Tax payable

After-tax dividend income

\begin{tabular}{|c|c|c|c|}
\hline $1 \%$ & $1 \%$ & $1 \%$ & $1 \%$ \\
\hline 7,000 & 7,000 & 8,150 & 8,150 \\
\hline 3,000 & & 1,350 & \\
\hline 10,000 & 7,000 & 9,500 & 8,150 \\
\hline $35 \%$ & $15 \%$ & $35 \%$ & $15 \%$ \\
\hline 3,500 & 1,050 & 3,325 & 1,223 \\
\hline$(3,000)$ & 0 & $(1,350)$ & 0 \\
\hline 500 & 1,050 & 1,975 & 1,223 \\
\hline 6,500 & 5,950 & 6,175 & 6,928 \\
\hline
\end{tabular}

The main interest in this example is the "After-tax dividend income" at the bottom line. The difference between columns (1) and (2) indicates that, even with a marginal tax rate of $35 \%$, dividend imputation compared to a dividend tax rate of $15 \%$ for the classical system, the shareholder receives almost 10\% more after tax income. Columns (3) and (4) introduce a level of tax avoidance whereby a deduction reduces taxable income by $50 \%$. The cost of the deduction is $10 \%$ of its value and reduces Net Profit before Tax. The tax avoidance reduces the After-tax Dividend Income for the shareholder under imputation but increases it under the classical system. It reverses the difference between the two shareholders, leaving the shareholder under imputation over $10 \%$ worse off them under the classical system. This is the effect of the additional costs associated with tax avoidance being passed on to shareholders. 


\section{References}

Adams, R.B. \& Ferreira, D. (2007). A Theory of Friendly Boards. Journal of Finance, 62(1), 217-2050. doi: 10.1111/j.1540-6261.2007.01206.x

Adhikari, A., Derashid, C., \& Zhang, H. (2006). Public policy, political connections, and effective tax rates: Longitudinal evidence from Malaysia. Journal of Accounting and Public Policy, 25(5), 574-595. doi:10.1016/j.jaccpubpol.2006.07.001

Ainsworth, A., Fong, K. Y., Gallagher, D. R., \& Partington, G. (2016). Institutional trading around the ex-dividend day. Australian Journal of Management, 41, 299-323. doi: $10.1177 / 0312896214539967$

Allen, F. \& Michaely, R. (2003). Chapter 7 - Payout policy. In G.M. Constantinides, M. Harris and R. Stulz (Eds.), Handbook of the Economics of Finance: Corporate Finance (Vol. 1). pp. 337-429, Elsevier B.V. doi:10.1016/S1574-0102(03)01011-2

Amiram, D., Bauer, A. M., \& Frank, M. M. (2016). Tax Avoidance at Public Corporations Driven by Shareholder Taxes: Evidence from Changes in Dividend Tax Policy, (Darden Business School Working Paper No. 2111467, July 07, 2016). Columbia University, University of Illinois and University of Virginia. doi.org/10.2139/ssrn.2111467

Amiram, D., \& Frank, M. M. (2015). Foreign Portfolio Investment and Shareholder Dividend Taxes. The Accounting Review, 91(3), 717-740. doi:10.2308/accr-51264

Anderson, R.C., \& Reeb, D.M. (2004). Board Composition: Balancing Family Influence in S\&P 500 Firms. Administrative Science Quarterly, 49(2), 209-237. doi.org/10.2307/4131472

Armstrong, C. S., Blouin, J. L., Jagolinzer, A.D. \& Larcker, D. F. (2015). Corporate governance, incentives, and tax avoidance. Journal of Accounting and Economics, 60(1), 1-17. doi-org.ezproxy.lib.uts.edu.au/10.1016/j.jacceco.2015.02.003

Armstrong, C. S., Blouin, J. L., \& Larcker, D. F. (2012). The incentives for tax planning. Journal of Accounting and Economics, 53(1), 391-411. doi:10.1016/j.jacceco.2011.04.001

Auerbach, A. J., \& Slemrod, J. (1997). The economic effects of the Tax Reform Act of 1986. Journal of Economic Literature, 35(2), 589-632. Retrieved from http://www.jstor.org/stable/2729788

Austin, C.R. \& Wilson, R. (2015). Are Reputational Costs a Determinant of Tax Avoidance? University of South Carolina, University of Oregon Working Paper, January 2015.

Babcock, J. (2000). The effects of imputation systems on multinational investment, financing, and income-shifting strategies. Journal of the American Taxation Association, 22(2), 1-21. doi:10.2308/jata.2000.22.2.1 
Badertscher, B. A., Katz, S. P., \& Rego, S. O. (2013). The separation of ownership and control and corporate tax avoidance. Journal of Accounting and Economics, 56(2), 228-250. doi:10.1016/j.jacceco.2013.08.005

Bhattacharya, S. (1979). Imperfect Information, Dividend Policy, and "The Bird in the Hand" Fallacy. The Bell Journal of Economics, 10(1), 259-270. doi: 10.2307/3003330

Bellamy, D. E. (1994). Evidence of imputation clienteles in the Australian equity market. Asia Pacific Journal of Management, 11(2), 275-287. doi:10.1007/BF01739203

Blouin, J. (2014). Defining and Measuring Tax Planning Aggressiveness. National Tax Journal, 67(4), 875-900.

Blouin, J., \& Krull, L. (2009). Bringing it home: A study of the incentives surrounding the repatriation of foreign earnings under the American Jobs Creation Act of 2004. Journal of Accounting Research, 47(4), 1027-1059. doi:10.1111/j.1475679X.2009.00342.X

Boone, J. P., Khurana, I. K., \& Raman, K. K. (2012). Religiosity and tax avoidance. The Journal of the American Taxation Association, 35(1), 53-84. doi:10.2308/atax-50341

Cannavan, D., Finn, F., \& Gray, S. (2004). The value of dividend imputation tax credits in Australia. Journal of Financial Economics, 73(1), 167-197. doi:10.1016/j.jfineco.2003.09.001

Chen, K. P., \& Chu, C. C. (2005). Internal control versus external manipulation: A model of corporate income tax evasion. RAND Journal of Economics, 151-164. Retrieved from http://www.jstor.org/stable/1593759

Chen, M. C., \& Gupta, S. (2011). An empirical investigation of the effect of imputation credits on remittance of overseas dividends. Journal of Contemporary Accounting \& Economics, 7(1), 18-30. doi:10.1016/j.jcae.2011.06.001

Chen, S., Chen, X., Cheng, Q., \& Shevlin, T. (2010). Are family firms more tax aggressive than non-family firms?. Journal of Financial Economics, 95(1), 41-61. doi:10.1016/j.jfineco.2009.02.003

Chetty, R., \& Saez, E. (2010). Dividend and Corporate Taxation in an Agency Model of the Firm. American Economic Journal: Economic Policy, 2(3), 1-31. Stable URL: http://www.jstor.org/stable/25760072, Accessed: 11-08-2017 03:43 UTC

Chi, S. S., Pincus, M., \& Teoh, S. H. (2013). Mispricing of book-tax differences and the trading behavior of short sellers and insiders. The Accounting Review, 89(2), 511-543. doi:10.2308/accr-50644

Clausing, K. A. (2005). Tax holidays (and other escapes) in the American Jobs Creation Act. National Tax Journal, 331-346. Retrieved from http://www.jstor.org/stable/41790272

Coles, J.L., Daniel, N.D., \& Naveeen, L. (2008). Boards: Does one size fit all? Journal of Financial Economics, 87(2), 329-356. doi.org/10.1016/j.jfineco.2006.08.008 
Cook, K. A., Moser, W., \& Omer, T. C. (2015). Tax Avoidance and Ex Ante Cost of Capital (Working Paper, December 10, 2015). Texas Tech University, Miami University of Ohio, and University of Nebraska-Lincoln. doi:0.2139/ssrn.2404032

Coulton, J. J., Ruddock, C. (2011). Corporate payout policy in Australia and a test of the lifecycle theory. Accounting and Finance, 51(1), 381-407. doi: 10.1111/j.1467629X.2010.00356.x

Coulton, J. J., Ruddock, C., \& Taylor, S. L. (2014). The Informativeness of Dividends and Associated Tax Credits. Journal of Business Finance \& Accounting, 41(9-10), 1309doi:1336. 10.1111/jbfa.12095

Dahya, J., \& McConnell, J.J. (2005). Outside directors and corporate board decisions. Journal of Corporate Finance, 11(1-2), 37-60. doi.org/10.1016/j.jcorpfin.2003.10.001

Dastyari, S. (2015, April 8). Why companies that avoid tax should be named and shamed, The Sydney Morning Herald. Retrieved from http://www.smh.com.au/comment/whycompanies-that-avoid-tax-should-be-named-and-shamed-20150406-1mfi98.html

DeAngelo, H., DeAngelo, L. \& Stulz, R.M. (2006). Dividend policy and the earned/contributed capital mix: a test of the life-cycle theory. Journal of Financial Economics, 81, 227-254.

Desai, M. A., \& Dharmapala, D. (2006). Corporate tax avoidance and high-powered incentives. Journal of Financial Economics, 79(1), 145-179. doi:10.1016/j.jfineco.2005.02.002

Desai, M. A., \& Dharmapala, D. (2009). Corporate tax avoidance and firm value. The Review of Economics and Statistics, 91(3), 537-546. doi:10.1162/rest.91.3.537

Desai, M. A., Dyck, A., \& Zingales, L. (2007). Theft and taxes. Journal of financial economics, 84(3), 591-623. doi:10.1016/j.jfineco.2006.05.005

Desai, M. A., \& Jin, L. (2011). Institutional tax clienteles and payout policy. Journal of financial economics, 100(1), 68-84. doi:10.1016/j.jfineco.2010.10.013

Dhaliwal, D.S., Erickson, M. \& Trezevant, R. (1999). A Test of the Theory of Tax Clienteles for Dividend Policies. National Tax Journal, 52(2), 179-194. Accessed at: EBSCOhost, www.lib.uts.edu.au/goto?url=http://search.ebscohost.com.ezproxy.lib.uts.edu.au/login. aspx?direct $=$ true $\& d b=$ heh $\& A N=1974932 \&$ site $=$ ehost-live.

Dunbar, A., Higgins, D., Phillips, J., \& Plesko, G. (2010). What do measures of tax aggressiveness measure. In Proceedings of the National Tax Association Annual Conference on Taxation (pp. 18-26). Retrieved from http://www.jstor.org/stable/prancotamamnta.103.18

Dyreng, S. D., Hanlon, M., \& Maydew, E. L. (2008). Long-run corporate tax avoidance. The Accounting Review, 83(1), 61-82. doi:10.2308/accr.2008.83.1.61

Dyreng, S., Hoopes, J., \& Wilde, J. (2014). Real Costs of Subsidiary Disclosure: Evidence from Corporate Tax Behavior (Working Paper, May 22, 2014). University of Iowa. Retrieved from http://fisher.osu.edu/supplements/10/14262/JWilde_Paper.pdf 
Easton, P.D. \& Harris, T.S. (1991). Earnings as an Explanatory Variable for Returns. Journal of Accounting Research, 29(1), 19-36.

Edwards, A., Schwab, C. \& Shevlin, T. (2016). Financial Constraints and Cash Tax Savings. The Accounting Review, 91(3), 859-881.

Elton, E.J. \& Gruber, M.J. (1970). Marginal Stockholder Tax Rates and the Clientele Effect. The Review of Economics and Statistics, 52(1), 68-74. Accessed at http://www.jstor.org/stable/1927599

Fama, E.F. (1980). Agency Problems and the Theory of the Firm. Journal of Political Economy, 88(2), 288-307. doi.org/10.1086/260866

Fama, E.F., \& Jensen, M.C. (1983). Separation of Ownership and Control. The Journal of Law and Economics, 26(2), 301-325. doi.org/10.1086/467037

Finkelstein, S., \& Mooney, A. C. (2003). Not the usual suspects: How to use board process to make boards better. The Academy of Management Executive, 17(2), 101-113.

Frank, M. M., Lynch, L. J., \& Rego, S. O. (2009). Tax reporting aggressiveness and its relation to aggressive financial reporting. The Accounting Review, 84(2), 467-496. doi:10.2308/accr.2009.84.2.467

Frischmann, P. J., Shevlin, T., \& Wilson, R. (2008). Economic consequences of increasing the conformity in accounting for uncertain tax benefits. Journal of Accounting and Economics, 46(2), 261-278. doi:10.1016/j.jacceco.2008.08.002

Fullerton, D. (1984). Which Effective Tax Rate? National Tax Journal, 37(1), 23-41. Retrieved from http://www.jstor.org/stable/41791931

Givoly, D., Hayn, C., Ofer, A. R., \& Sarig, O. (1992). Taxes and capital structure: Evidence from firms' response to the Tax Reform Act of 1986. Review of Financial Studies, 5(2), 331-355. doi:10.1093/rfs/5.2.331

Graham, J. R., Hanlon, M., Shevlin, T., \& Shroff, N. (2013). Incentives for tax planning and avoidance: Evidence from the field. The Accounting Review, 89(3), 991-1023. doi:10.2308/accr-50678

Graham, J. R., \& Kumar, A. (2006). Do dividend clienteles exist? Evidence on dividend preferences of retail investors. The Journal of Finance, 61(3), 1305-1336. doi:10.1111/j.1540-6261.2006.00873.x

Graham, J. R., \& Tucker, A. L. (2006). Tax shelters and corporate debt policy. Journal of Financial Economics, 81(3), 563-594. doi:10.1016/j.jfineco.2005.09.002

Guenther, D. A. (1994). Earnings management in response to corporate tax rate changes: Evidence from the 1986 Tax Reform Act. The Accounting Review, 69(1), 230-243. Retrieved from http://www.jstor.org/stable/248269

Guernther, D.A., Matsunaga, S.R. \& Williams, B.M. (2016). Is Tax Avoidance Related to Firm Risk? The Accounting Review, Pre-print of accepted Manuscript, Jan. 2016. 
Gupta, S., \& Newberry, K. (1997). Determinants of the variability in corporate effective tax rates: Evidence from longitudinal data. Journal of Accounting and Public Policy, 16(1), 1-34. doi:10.1016/S0278-4254(96)00055-5

Hail, L., Tahoun, A., \& Wang, C. (2014). Dividend Payouts and Information Shocks. Journal of Accounting Research, 52(2), 403-456. doi: 10.1111/1475-679X.12040

Hamson, D. \& Ziegler, P. (1990). The Impact of Dividend Imputation on Firms' Financial Decisions. Accounting and Finance, 1990(Nov), 29-53.

Hanlon, M. (2005). The persistence and pricing of earnings, accruals, and cash flows when firms have large book-tax differences. The Accounting Review, 80(1), 137-166. doi:10.2308/accr.2005.80.1.137

Hanlon, M., \& Heitzman, S. (2010). A review of tax research. Journal of Accounting and Economics, 50(2), 127-178. doi:10.1016/j.jacceco.2010.09.002

Hanlon, M., \& Slemrod, J. (2009). What does tax aggressiveness signal? Evidence from stock price reactions to news about tax shelter involvement. Journal of Public Economics, 93(1), 126-141. doi:10.1016/j.jpubeco.2008.09.004

Harrington, C., \& Smith, W. (2012). Tax avoidance and corporate capital structure. Journal of Finance and Accountancy, 11, 1948-3015.

Hathaway, N. (2013). Imputation Credit Redemption ATO data 1988-2011: Where have all the credits gone? Capital Research, Melbourne, Vic. Retrieved from http://www.erawa.com.au/cproot/11760/2/Attachment $\% 206 \% 20$ -

$\% 20$ Hathaway\%20Capital\%20Research\%20-

\%20Imputation\%20Credit\%20Redemption\%20ATO\%20Data.pdf

Heaney, R. A. (2011). The Existence of Tax Clienteles: An Australian Setting (Working Paper, October 10, 2011). University of Western Australia. doi:10.2139/ssrn.1966835

Henry, D. (2011). Ownership structure and tax-friendly dividends. Journal of Banking \& Finance, 35(1), 2747-2760. doi:10.1016/j.jbankfin.2011.03.003

Hermalin, B.E. \& Weisbach, M.S. (1988). The determinants of board composition. RAND Jounal of Economics, 19(4), 589-606. Retrieved from http://www.jstor.org/stable/2555459

Hoi, C. K., Wu, Q., \& Zhang, H. (2013). Is corporate social responsibility (CSR) associated with tax avoidance? Evidence from irresponsible CSR activities. The Accounting Review, 88(6), 2025-2059. doi:10.2308/accr-50544

Howard, P.F. \& Brown, R.L. (1992). Dividend Policy and Capital Structure under the Imputation Tax System: Some Clarifying Comments. Accounting and Finance, 1992(May), 51-61.

Ikin, C., \& Tran, A. (2013). Corporate tax strategy in the Australian dividend imputation system. Australian Tax Forum, 28(3), 523-553. Retrieved from SSRN: http://ssrn.com/abstract $=2707989$ 
Inger, K. K. (2013). Relative valuation of alternative methods of tax avoidance. The Journal of the American Taxation Association, 36(1), 27-55. doi:10.2308/atax-50606

Jimenez-Angueira, C.E. (2008). Tax Aggressiveness, Tax Environment Changes, and Corporate Governance. Doctoral Dissertation, University of Florida, 2008.

Joint Committee on Taxation, (1999). Description and Analysis of Present-law Tax Rules and Recent Proposals Relating to Corporate Tax Shelter (Report, JCX-84-99), November 10, 1999. Retrieved from http://www.jct.gov/x-84-99.pdf

Jun, A., Gallagher, D. R., \& Partington, G. H. (2011). Institutional dividend clienteles under an imputation tax system. Journal of Business Finance \& Accounting, 38(1-2), 198224. doi:10.1111/j.1468-5957.2010.02214.x

Khurana, I. K., \& Moser, W. J. (2012). Institutional shareholders' investment horizons and tax avoidance. The Journal of the American Taxation Association, 35(1), 111-134. doi:10.2308/atax-50315

Kim, J. B., Li, Y., \& Zhang, L. (2011). Corporate tax avoidance and stock price crash risk: Firm-level analysis. Journal of Financial Economics, 100(3), 639-662. doi:10.1016/j.jfineco.2010.07.007

Korkeamaki, T., Liljeblom, E., \& Pasternack, D. (2010). Tax reform and payout policy: Do shareholder clienteles or payout policy adjust?. Journal of Corporate Finance, 16(4), 572-587. doi:10.1016/j.jcorpfin.2009.12.003

Lally, M. (2012). The Estimated Utilisation Rate for Imputation Credits (Working Paper, 12 December 2012). Victoria University of Wellington. doi:10.1.1.401.1603

Lanis, R., \& Richardson, G. (2011). The effect of board of director composition on corporate tax aggressiveness. Journal of Accounting \& Public Policy, 30(1), 50-70. doi:10.1016/j.jaccpubpol.2010.09.003

Lanis, R., \& Richardson, G. (2012). Corporate social responsibility and tax aggressiveness: a test of legitimacy theory. Accounting, Auditing \& Accountability Journal, 26(1), 75100. doi:10.1108/09513571311285621

Lasfer, M.A. (1996). Taxes and dividends: The UK evidence. Journal of Banking and Finance, 20, 455-472. doi.org/10.1016/0378-4266(95)00012-7

Lennox, C.S., Francis, J.R., \& Wang, Z., (2012). Selection Models in Accounting Research. The Accounting Review, 87(2). 589-616. doi: 10.2308/accr-10195

Levin, C., (2013, May). Offshore profit shifting and the US tax code-part 2 (Apple Inc.)(Report, May 21, 2013). Statement before U.S. Permanent Subcommittee on Investigations. U.S. Congress, Washington D.C. Retrieved from http://www.hsgac.senate.gov/subcommittees/investigations/hearings/offshore-profitshifting-and-the-us-tax-code-part-2

Lintner, J. (1956). Distribution of Incomes of Corporations Among Dividends, Retained Earnings, and Taxes. The American Economic Review, 46(2), 97-113. Stable URL: http://www.jstor.org/stable/1910664, accessed 17 August 2017. 
Lisowsky, P., Robinson, L., \& Schmidt, A. (2013). Do publicly disclosed tax reserves tell us about privately disclosed tax shelter activity? Journal of Accounting Research, 51(3), 583-629. doi:10.1111/joar.12003

Mace, M. (1986). Directors: Myth and Reality (Harvard Business School Press, Boston, MA)

Maheshwari, S. (2014, August 7). Walgreens Decides To Remain U.S. Company After Public Shaming. BuzzFeed News. Retrieved from https:/www.buzzfeed.com/sapna/walgreens-abandons-relocation-scheme-to-avoid-ustaxes-after?utm_term=.duXq7DZZZR\#.iaBO3bRRR4

McGuire, S. T., Omer, T. C., \& Wilde, J. H. (2013). Investment opportunity sets, operating uncertainty, and capital market pressure: Determinants of investments in tax shelter activities? The Journal of the American Taxation Association, 36(1), 1-26. doi:10.2308/atax-50599

Miller, M.H. \& Modigliani, F. (1961). Dividend Policy, Growth, and the Valuation of Shares. Journal of Business, 34(4), 411-433. Stable URL: http://www.jstor.org/stable/2351143, Accessed: 17-09-2017 14:35 UTC

Minnick, K. \& Noga, T. (2010). Do corporate governance characteristics influence tax management? Journal of Corporate Finance, 16(3), 703-718. doi:10.1016/j.jcorpfin.2010.08.005

Newnham, M. (2017). Escaping the small business company tax trap. The Sydney Moring Herald, 22 August 2017, Accessed at: http://www.smh.com.au/smallbusiness/finance/escaping-the-small-businesscompany-tax-trap-20170821gy0o1w.html, on 24 August 2017.

OECD (2015). Table II.4. Overall statutory tax rates on dividends. OECD Tax Database, Retrieved December 04, 2015, from http://www.oecd.org/ctp/tax-policy/Table\%20II.4May-2014.xlsx

Officer, R. R. (1994). The cost of capital of a company under an imputation tax system. Accounting \& Finance, 34(1), 1-17. doi:10.1111/j.1467-629X.1994.tb00259.x

Omer, T. C., Molloy, K. H., \& Ziebart, D. A. (1993). An investigation of the firm sizeeffective tax rate relation in the 1980s. Journal of Accounting, Auditing \& Finance, 8(2), 167-182. doi:10.1177/0148558X9300800206

Pfeffer, J. \& Salancik, G.R. (1978). The External Control of Organizatons. Harper \& Row, New York

Poterba, J. (2004). Taxation and corporate payout policy (NBER Working Paper Series No. w10321). National Bureau of Economic Research, Cambridge MA. doi:10.3386/w10321

Prevost, A., Rao, R. P., \& Wagster, J. D. (2002). Dividend imputation and shareholder wealth: The case of New Zealand. Journal of Business Finance \& Accounting, 29(7-8), 1079-1104. doi:10.1111/1468-5957.00462 
Rego, S. O. (2003). Tax-avoidance activities of US multinational corporations. Contemporary Accounting Research, 20(4), 805-833. doi:10.1506/VANN-B7UBGMFA-9E6W

Rego, S. O., \& Wilson, R. (2012). Equity risk incentives and corporate tax aggressiveness. Journal of Accounting Research, 50(3), 775-810. doi:10.1111/j.1475679X.2012.00438.x

Reserve Bank of New Zealand, 1996, New Zealand's remarkable reforms, accessed at: http://www.rbnz.govt.nz/research-and-publications/speeches/1996/speech1996-06-04, on 9 Aug 2017.

Rindova, V. P., \& Fombrun, C. J. (1999). Constructing competitive advantage: The role of firm-constituent interactions. Strategic management journal, 20(8), 691-710. Retrieved from http://www.jstor.org/stable/3094244

Rosenstein, S., \& Wyatt, J.G. (1990). Outside directors, board independence, and shareholder wealth. Journal of Financial Economics, 26(2), 175-191. doi.org/10.1016/0304405X(90)90002-H

Saavedra, D. (2013). Analysis of unsuccessful tax avoiders (Working Paper, September 30, 2013). University of California Los Angeles. doi:10.2139/ssrn.2486917

Scholes, M.S., \& Wolfson, M.A. (1992). Taxes and Business Strategy; A Planning Approach (First Ed.). Pearson Prentice-Hall, Upper Saddle Rivers NJ.

Schulman, C. T., Thomas, D. W., Sellers, K. F., \& Kennedy, D. B. (1996). Effects of tax integration and capital gains tax on corporate leverage. National Tax Journal, 31-54. Retrieved from http://www.jstor.org/stable/41789184

Slemrod, J. (2004). The economics of corporate tax selfishness (NBER Working Paper No. 10858). National Bureau of Economic Research. doi:10.3386/w10858

Starbucks suffers reputation slump over tax 'avoidance' (2012, October 19). The Week. Retrieved from http://www.theweek.co.uk/business/49650/starbucks-suffersreputation-slump-over-tax-avoidance

Stickney, C. P., \& McGee, V. E. (1983). Effective corporate tax rates the effect of size, capital intensity, leverage, and other factors. Journal of accounting and public policy, 1(2), 125-152. doi:10.1016/S0278-4254(82)80004-5

Treasury (1986) Some economic implications of takeovers (Treasury Economic Paper No. 12). The Australian Treasury Department, Australian Government Printing Service, Canberra ACT. Retrieved from http://www.takeovers.gov.au/content/Resources/other.../economic_implications.pdf

Treasury (2015). Re:think - Tax discussion paper (Discussion Paper, March 2015). The Australian Government the Treasury, Canberra. Retrieved from http://bettertax.gov.au/files/2015/03/TWP_combined-online.pdf 
Twite, G. (2001). Capital structure choices and taxes: Evidence from the Australian dividend imputation tax system. International Review of Finance, 2(4), 217-234. doi:10.1111/1468-2443.00027

Wilkinson, B. R., Cahan, S. F., \& Jones, G. (2001). Strategies and dividend imputation: the effect of foreign and domestic ownership on average effective tax rates. Journal of International Accounting, Auditing and Taxation, 10(2), 157-175. doi:10.1016/S10619518(01)00042-8

Wilson, R. J. (2009). An examination of corporate tax shelter participants. The Accounting Review, 84(3), 969-999. doi:10.2308/accr.2009.84.3.969

Zimmerman, J. L. (1983). Taxes and firm size. Journal of accounting and economics, 5, 119149. doi:10.1016/0165-4101(83)90008-3 
Table 1: Sample selection

Panel A: Full Sample

Firm-years listed on the ASX - 2004 to 2015

21,384

Less Loss observations

$-12,422$
8,962

Less Financial \& Utilities firms

$-2,157$

6,805

Less Missing data

-914
5,981

Less Missing Outside Directors data

$-1,162$

Full Sample (Main Regression)

4,729

Panel B: Foreign Ownership Sample

Ownership data available - 2015 only

326

Less Loss observations

$-78$

Less Financial \& Utilities firms

197

Less Missing data

Foreign Ownership Sample

196

Table 1: Sample selection - Clientele Samples

\begin{tabular}{|l|cc|cc|cc|cc|}
\hline \multirow{2}{*}{ Panel C: Industry } & \multicolumn{2}{|c|}{ NoDiv } & \multicolumn{2}{|c|}{ DivNTC } & \multicolumn{2}{c|}{ DivTC } & \multicolumn{2}{c|}{ Full Sample } \\
& $N$ & $\%$ & $N$ & $\%$ & $N$ & $\%$ & $N$ & $\%$ \\
\hline Energy & 191 & 0.128 & 34 & 0.073 & 150 & 0.054 & 375 & 0.079 \\
Materials & 440 & 0.294 & 88 & 0.188 & 358 & 0.129 & 886 & 0.187 \\
Industrial & 240 & 0.160 & 80 & 0.171 & 727 & 0.263 & 1047 & 0.221 \\
Consumer Discretionary & 215 & 0.144 & 94 & 0.201 & 652 & 0.236 & 961 & 0.203 \\
Consumer Staples & 69 & 0.046 & 44 & 0.094 & 201 & 0.073 & 314 & 0.066 \\
Health Care & 104 & 0.070 & 37 & 0.079 & 151 & 0.055 & 292 & 0.062 \\
Information Technology & 151 & 0.101 & 64 & 0.137 & 223 & 0.081 & 438 & 0.093 \\
Telecommunications & 58 & 0.039 & 19 & 0.041 & 253 & 0.091 & 330 & 0.070 \\
Real Estate & 28 & 0.019 & 7 & 0.015 & 51 & 0.018 & 86 & 0.018 \\
\hline Total & 1496 & 1.000 & 467 & 1.000 & 2766 & 1.000 & 4729 & 1.000 \\
\hline
\end{tabular}


Table 1: Sample Selection - Clientele Samples

\begin{tabular}{|l|cc|cc|cc|cc|}
\hline Panel D: Year & \multicolumn{2}{|c|}{ NoDiv } & \multicolumn{2}{c|}{ DivNTC } & \multicolumn{2}{c|}{ DivTC } & \multicolumn{2}{c|}{ Full Sample } \\
& $N$ & $\%$ & $N$ & $\%$ & $N$ & $\%$ & $N$ & $\%$ \\
\hline 2004 & 90 & 0.060 & 35 & 0.075 & 209 & 0.076 & 334 & 0.071 \\
2005 & 89 & 0.059 & 31 & 0.066 & 241 & 0.087 & 361 & 0.076 \\
2006 & 113 & 0.076 & 36 & 0.077 & 238 & 0.086 & 387 & 0.082 \\
2007 & 97 & 0.065 & 42 & 0.090 & 251 & 0.091 & 390 & 0.082 \\
2008 & 122 & 0.082 & 33 & 0.071 & 260 & 0.094 & 415 & 0.088 \\
2009 & 128 & 0.086 & 28 & 0.060 & 218 & 0.079 & 374 & 0.079 \\
2010 & 166 & 0.111 & 52 & 0.111 & 235 & 0.085 & 453 & 0.096 \\
2011 & 161 & 0.108 & 41 & 0.088 & 234 & 0.085 & 436 & 0.092 \\
2012 & 142 & 0.095 & 44 & 0.094 & 233 & 0.084 & 419 & 0.089 \\
2013 & 138 & 0.092 & 40 & 0.086 & 224 & 0.081 & 402 & 0.085 \\
2014 & 136 & 0.091 & 46 & 0.099 & 222 & 0.080 & 404 & 0.085 \\
2015 & 114 & 0.076 & 39 & 0.084 & 201 & 0.073 & 354 & 0.075 \\
\hline Total & 1496 & 1.000 & 467 & 1.000 & 2766 & 1.000 & 4729 & 1.000 \\
\hline
\end{tabular}


Table 2: Descriptive statistics - Full Sample

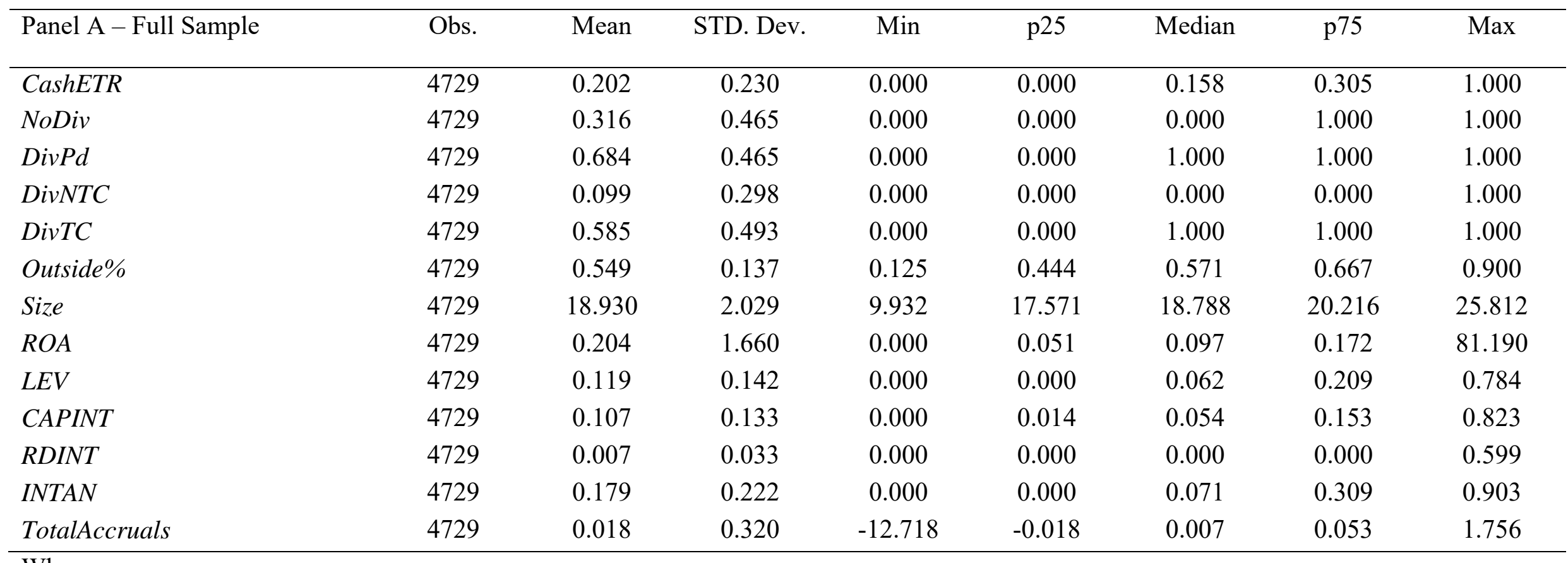

Where:

CashETR $_{i t} \quad:$ Tax paid (cash) for firm $i$ in year $t$ divided by profit before tax for firm $i$ in year $t$

NoDivit $_{i} \quad$ : Dichotomous variable assuming the value 1 if firm $i$ does not pay a dividend in year $t$, else 0 .

$\operatorname{DivPd}_{i t} \quad:$ Dichotomous variable assuming the value 1 if firm $i$ pays a dividend in year $t$, else 0 .

$\operatorname{DivNTC}_{i t} \quad:$ Dichotomous variable assuming the value 1 if firm $i$ pays a dividend without a tax credit in year $t$, else 0.

DivTC $_{i t} \quad$ : Dichotomous variable assuming the value 1 if firm $i$ pays a dividend with a tax credit in year $t$, else 0 .

Foreign $_{i} \quad:$ Percent of shares held by non-resident shareholders for firm $i$ in 2015

$S_{S I Z E_{i t}} \quad: \quad$ Natural Log of total assets for firm $i$ in year $t$ in year $t$

$R O A_{i t} \quad:$ : Profit before tax for firm $i$ in year $t$ divided by average assets in year $t$

$L E V_{\text {it }} \quad:$ Long-term debt for firm $i$ in year $t$ divided by total assets in year $t$

CAPINT $_{\text {it }} \quad:$ Property, plant and equipment for firm $i$ in year $t$ divided by total assets in year $t$

$R_{\text {RDINT }}$ it $\quad:$ Research and development expense for firm $i$ in year $t$ divided by total assets in year $t$

INTAN $N_{\text {it }} \quad:$ Total intangible assets for firm $i$ in year $t$ divided by total assets in year $t$

TotalAccruals $_{\text {it }} \quad$ : Net increase in cash flow minus net income for firm $i$ in year $t$ divided by total assets in year $t$ 
Table 2: Descriptive statistics - Foreign Ownership Sample

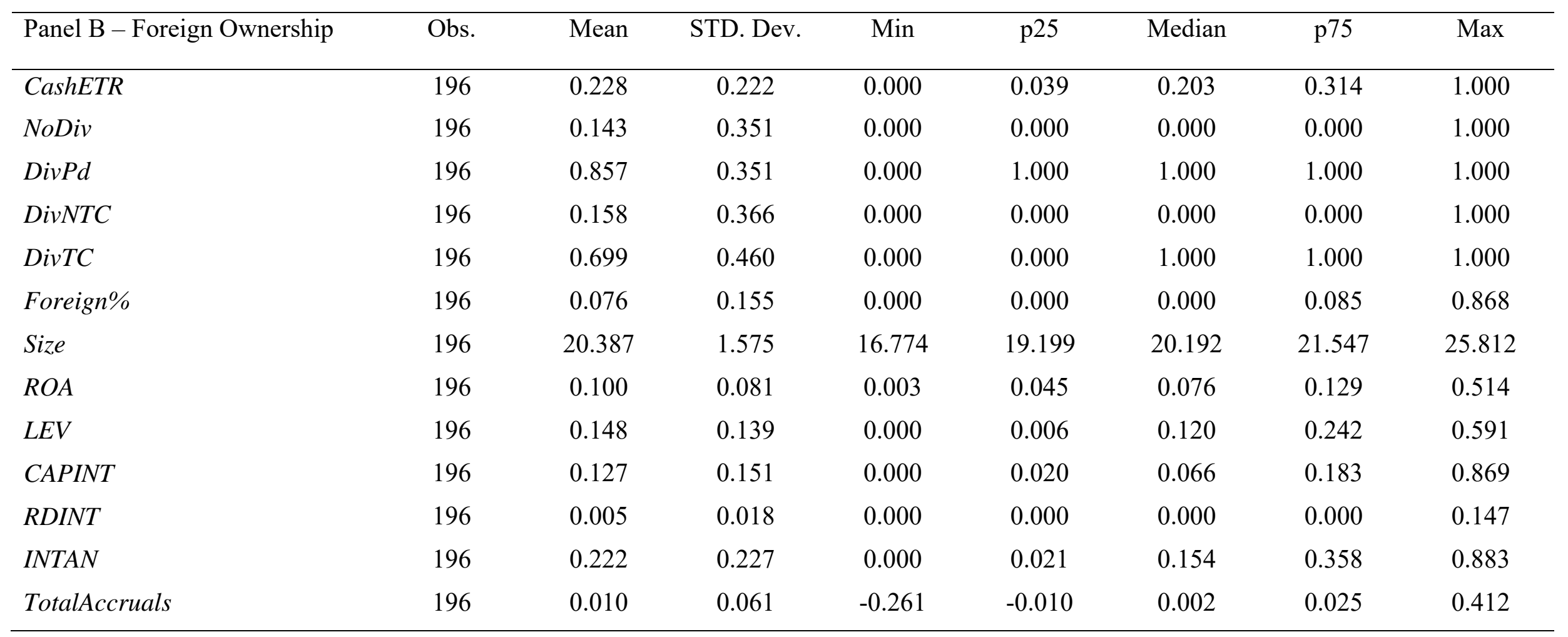


Table 2: Descriptive statistics - Clientele Samples

\begin{tabular}{lcccc}
\hline Panel C - Means only & NoDiv & DivNTC & DivTC & Full Sample \\
\hline CashETR & 0.111 & 0.107 & 0.268 & 0.202 \\
DivNTC & 0.000 & 1.000 & 0.000 & 0.099 \\
DivTC & 0.000 & 0.000 & 1.000 & 0.585 \\
Outside\% & 0.514 & 0.576 & 0.563 & 0.549 \\
Foreign\% (a) & 0.160 & 0.200 & 0.041 & 0.076 \\
Size & 17.628 & 19.388 & 19.558 & 18.930 \\
ROA & 0.313 & 0.236 & 0.140 & 0.204 \\
LEV & 0.081 & 0.141 & 0.135 & 0.119 \\
CAPINT & 0.081 & 0.102 & 0.121 & 0.107 \\
RDINT & 0.007 & 0.013 & 0.005 & 0.007 \\
INTAN & 0.119 & 0.139 & 0.218 & 0.179 \\
TotalAccruals & 0.040 & 0.018 & 0.007 & 0.018 \\
Obs & 1496 & 467 & 2766 & 4729 \\
\%age & $31.6 \%$ & $9.9 \%$ & $58.5 \%$ & $100 \%$
\end{tabular}

(a) Foreign\%: Obs $=191\left(\right.$ NoDivit $_{i t}=27 ;$ DivNTC $_{i t}=31$; Div\&TC $\left._{i t}=133\right)$ 
Table 3: Correlation Matrices

Panel A: Full Sample (Obs. = 4,729)

\begin{tabular}{|c|c|c|c|c|c|c|c|c|c|c|c|c|}
\hline & CashETR & NoDiv & DivNTC & DivTC & Outside\% & Size & $R O A$ & $L E V$ & CAPINT & RDINT & INTAN & TotAcc's \\
\hline CashETR & & -0.272 & -0.138 & 0.340 & 0.008 & 0.203 & -0.047 & 0.090 & 0.083 & -0.025 & 0.167 & -0.054 \\
\hline NoDiv & -0.431 & & -0.225 & -0.808 & -0.172 & -0.437 & 0.045 & -0.181 & -0.132 & 0.012 & -0.183 & 0.046 \\
\hline DivNTC & -0.175 & -0.225 & & -0.393 & 0.065 & 0.075 & 0.007 & 0.052 & -0.011 & 0.059 & -0.060 & -0.000 \\
\hline DivTC & 0.513 & -0.808 & -0.393 & & 0.123 & 0.367 & -0.046 & 0.140 & 0.131 & -0.048 & 0.209 & -0.043 \\
\hline Outside\% & 0.038 & -0.165 & 0.064 & 0.117 & & 0.319 & 0.025 & 0.090 & 0.105 & 0.037 & 0.025 & -0.007 \\
\hline Size & 0.291 & -0.441 & 0.077 & 0.369 & 0.338 & & -0.146 & 0.356 & 0.241 & -0.092 & 0.143 & -0.009 \\
\hline$R O A$ & 0.016 & -0.145 & -0.044 & 0.163 & -0.064 & -0.130 & & -0.044 & -0.038 & -0.002 & -0.044 & 0.072 \\
\hline$L E V$ & 0.195 & -0.252 & 0.030 & 0.220 & 0.101 & 0.457 & -0.197 & & 0.216 & -0.083 & 0.215 & -0.057 \\
\hline CAPINT & 0.209 & -0.216 & -0.004 & 0.206 & 0.100 & 0.255 & 0.000 & 0.337 & & -0.073 & -0.140 & -0.019 \\
\hline RDINT & 0.057 & -0.059 & 0.066 & 0.016 & 0.091 & 0.027 & 0.044 & 0.026 & 0.099 & & 0.006 & 0.016 \\
\hline INTAN & 0.306 & -0.280 & -0.059 & 0.300 & 0.044 & 0.180 & -0.066 & 0.329 & 0.120 & 0.113 & & -0.021 \\
\hline TotalAccruals & -0.171 & 0.093 & -0.016 & -0.078 & -0.041 & -0.094 & 0.174 & -0.121 & -0.081 & -0.005 & -0.078 & \\
\hline
\end{tabular}

Pearson correlations above diagonal, Spearman's rank correlations below.

Bold $=p<0.05$ 
Table 3: Correlation Matrices (Continued)

Panel B: Foreign Ownership Sample (Obs. = 196)

\begin{tabular}{|c|c|c|c|c|c|c|c|c|c|c|c|c|}
\hline & CashETR & NoDiv & DivNTC & DivTC & Foreign\% & Size & $R O A$ & $L E V$ & CAPINT & RDINT & INTAN & TotAcc's \\
\hline CashETR & & -0.041 & -0.113 & 0.121 & -0.109 & 0.011 & -0.119 & 0.148 & 0.013 & -0.031 & 0.212 & -0.095 \\
\hline NoDiv & -0.152 & & -0.177 & -0.622 & 0.208 & -0.115 & -0.236 & -0.028 & 0.195 & -0.096 & -0.168 & -0.040 \\
\hline DivNTC & -0.128 & -0.177 & & -0.661 & 0.221 & 0.186 & 0.076 & 0.107 & 0.011 & 0.280 & -0.061 & -0.033 \\
\hline DivTC & 0.217 & -0.622 & -0.661 & & -0.334 & -0.060 & 0.120 & -0.064 & -0.157 & -0.150 & 0.177 & 0.057 \\
\hline Foreign\% & -0.108 & 0.115 & 0.199 & -0.246 & & 0.059 & -0.054 & 0.078 & -0.093 & 0.002 & -0.059 & -0.113 \\
\hline Size & 0.026 & -0.124 & 0.219 & -0.080 & 0.199 & & -0.179 & 0.360 & 0.216 & -0.004 & 0.078 & -0.140 \\
\hline$R O A$ & -0.019 & -0.315 & 0.084 & 0.173 & -0.118 & -0.106 & & -0.149 & -0.096 & 0.417 & -0.005 & -0.112 \\
\hline LEV & 0.195 & -0.036 & 0.094 & -0.047 & 0.044 & 0.388 & -0.123 & & 0.194 & -0.011 & 0.230 & -0.136 \\
\hline CAPINT & 0.067 & 0.119 & -0.037 & -0.061 & -0.057 & 0.111 & -0.025 & 0.192 & & -0.080 & -0.240 & -0.100 \\
\hline RDINT & 0.065 & -0.097 & 0.171 & -0.061 & 0.032 & 0.063 & 0.267 & 0.078 & 0.086 & & 0.071 & -0.011 \\
\hline INTAN & 0.290 & -0.192 & -0.075 & 0.206 & 0.021 & 0.085 & 0.064 & 0.239 & -0.095 & 0.155 & & 0.047 \\
\hline TotalAccruals & -0.023 & -0.077 & -0.032 & 0.084 & -0.087 & -0.088 & 0.052 & -0.108 & -0.051 & -0.026 & 0.078 & \\
\hline
\end{tabular}

Pearson correlations above diagonal, Spearman's rank correlations below.

Bold $=p<0.05$ 
Table 4: Test of association between dividend imputation and corporate tax avoidance

CashETR $_{i t}=\propto_{0}+\propto_{1}$ DivTC $_{i t}+\propto_{2}$ DivNTC $_{i t}+\propto_{3}$ Outside $\%_{i t}+\propto_{4}$ Outside $\%_{i t} *$ DivTC $_{i t}$ $+\sum_{\gamma=5}^{k} \propto_{y}$ Controls $_{i t}+\sum_{k+1}^{j} \propto_{k}$ Indust $_{i t}+\sum_{j+1}^{l} \propto_{j}$ Year $_{i}+\varepsilon_{i t}$ CashETR CashETR CashETR

\begin{tabular}{|c|c|c|c|c|c|c|c|c|c|}
\hline & Coef. & t-stat. & & Coef. & t-stat. & & Coef. & t-stat. & \\
\hline Constant & -0.104 & -2.920 & $* *$ & -0.089 & -2.481 & $*$ & -0.104 & -2.590 & $* *$ \\
\hline DivTC & 0.123 & 13.163 & $* * *$ & 0.124 & 13.317 & $* * *$ & 0.147 & 5.432 & $* * *$ \\
\hline DivNTC & -0.022 & -1.849 & & -0.020 & -1.677 & & -0.022 & -1.793 & \\
\hline Outside\% & & & & -0.099 & -3.931 & $* * *$ & -0.076 & -2.038 & $*$ \\
\hline Outside\%*DivTC & & & & & & & -0.044 & -0.911 & \\
\hline Size & 0.009 & 5.024 & $* * *$ & 0.011 & 5.949 & $* * *$ & 0.012 & 6.004 & $* * *$ \\
\hline$R O A$ & -0.002 & -1.762 & & -0.001 & -1.305 & & -0.001 & -1.350 & \\
\hline$L E V$ & -0.028 & -1.225 & & -0.031 & -1.349 & & -0.032 & -1.385 & \\
\hline CAPINT & 0.076 & 2.887 & $* *$ & 0.080 & 3.060 & $* *$ & 0.079 & 3.030 & $* *$ \\
\hline RDINT & 0.058 & 0.774 & & 0.082 & 1.091 & & 0.082 & 1.088 & \\
\hline INTAN & 0.108 & 6.405 & $* * *$ & 0.107 & 6.353 & $* * *$ & 0.108 & 6.372 & $* * *$ \\
\hline TotalAccruals & -0.026 & -1.353 & & -0.026 & -1.368 & & -0.026 & -1.373 & \\
\hline Energy & 0.036 & 1.951 & & 0.035 & 1.884 & & 0.035 & 1.885 & \\
\hline Materials & 0.004 & 0.246 & & 0.002 & 0.174 & & 0.003 & 0.186 & \\
\hline Industrials & 0.035 & 2.476 & $*$ & 0.032 & 2.283 & $*$ & 0.032 & 2.264 & * \\
\hline Consumer Discretionary & 0.037 & 2.619 & $* *$ & 0.036 & 2.574 & $*$ & 0.036 & 2.571 & $*$ \\
\hline Consumer Staples & 0.004 & 0.244 & & 0.006 & 0.393 & & 0.007 & 0.424 & \\
\hline Health Care & -0.009 & -0.515 & & -0.008 & -0.464 & & -0.008 & -0.477 & \\
\hline Information Technology & 0.000 & -0.024 & & -0.001 & -0.087 & & -0.001 & -0.085 & \\
\hline Telecommunications & -0.027 & -1.388 & & -0.025 & -1.316 & & -0.025 & -1.309 & \\
\hline Observations & 4729 & & & 4729 & & & 4729 & & \\
\hline R-squared & 0.151 & & & 0.154 & & & 0.154 & & \\
\hline Adjusted R-squared & 0.146 & & & 0.149 & & & 0.149 & & \\
\hline F-Stat. & 37.51 & & & 37.58 & & & 36.33 & & \\
\hline Year Fixed Effects & Yes & & & Yes & & & Yes & & \\
\hline
\end{tabular}

${ }^{*} p<0.05,{ }^{* *} p<0.01, * * * p<0.001$

Where: 
CashETR $_{i t}$

NoDivit $_{i t}$

$\operatorname{DivPd}_{i t}$

$\operatorname{DivNTC}_{i t}$

$\operatorname{DivTC}_{i t}$

Foreign $\%_{i}$

$S I Z E_{i t}$

$R O A_{i t}$

$L E V_{i t}$

CAPINT $_{\text {it }}$

$R D I N T_{i t}$

$I_{N T A N}$

TotalAccruals $_{\text {it }}$
: Tax paid (cash) for firm $i$ in year $t$ divided by profit before tax for firm $i$ in year $t$

: Dichotomous variable assuming the value 1 if firm $i$ does not pay a dividend in year $t$, else 0 .

: Dichotomous variable assuming the value 1 if firm $i$ pays a dividend in year $t$, else 0 .

: Dichotomous variable assuming the value 1 if firm $i$ pays a dividend without a tax credit in year $t$, else 0 .

: Dichotomous variable assuming the value 1 if firm $i$ pays a dividend with a tax credit in year $t$, else 0 .

: Percent of shares held by non-resident shareholders for firm $i$ in 2015

: Natural Log of total assets for firm $i$ in year $\mathrm{t}$ in year $t$

: Profit before tax for firm $i$ in year $t$ divided by average assets in year $t$

: Long-term debt for firm $i$ in year $t$ divided by total assets in year $t$

: Property, plant and equipment for firm $i$ in year $t$ divided by total assets in year $t$

: Research and development expense for firm $i$ in year $t$ divided by total assets in year $t$

: Total intangible assets for firm $i$ in year $t$ divided by total assets in year $t$

: Net increase in cash flow minus net income for firm $i$ in year $t$ divided by total assets in year $t$ 
Table 5: Heterogeneity of the costs of tax avoidance

\begin{tabular}{|c|c|c|}
\hline & $\begin{array}{c}\text { DivTC } i t \\
\text { Coef. }\end{array}$ & t-stat. \\
\hline Constant & -1.033 & $-14.802 * * *$ \\
\hline Energy & -0.381 & $-12.129 * * *$ \\
\hline Materials & -0.338 & $-12.064 * * *$ \\
\hline Industrials & -0.074 & $-2.608 * *$ \\
\hline Consumer Discretionary & -0.080 & $-2.862 * *$ \\
\hline Consumer Staples & -0.177 & $-5.115 * * *$ \\
\hline Health Care & -0.240 & $-6.601 * * *$ \\
\hline Information Technology & -0.191 & $-5.606 * * *$ \\
\hline Telecommunications & -0.052 & -1.065 \\
\hline Size $_{t}$ & 0.090 & $27.280 * * *$ \\
\hline$R O A_{i t}$ & 0.006 & $3.079 * *$ \\
\hline$L E V_{i t}$ & -0.290 & $-5.607 * * *$ \\
\hline CAPINT $_{\text {it }}$ & 0.282 & $5.117 * * *$ \\
\hline$R_{D I N T_{i t}}$ & -0.222 & -1.078 \\
\hline INTANit & 0.318 & $9.315 * * *$ \\
\hline TotalAccrualsit & -0.046 & $-2.349 *$ \\
\hline Observations & 4729 & \\
\hline F-stat & 88.85 & \\
\hline R-squared & 0.237 & \\
\hline Adjusted R-squared & 0.233 & \\
\hline Year Fixed Effects & Yes & \\
\hline
\end{tabular}

Where:

DivTC $_{i t} \quad$ : Dichotomous variable assuming the value 1 if firm $i$ pays a dividend with a tax credit in year $t$, else 0 . 
Table 6: Test of association between dividend imputation and foreign ownership

${\text { Foreign } \%_{i t}}_{i t} \delta_{0}+\delta_{1}$ DivTC $_{i t}+\sum_{\gamma=2}^{k} \delta_{y}$ Controls $_{i t}+\sum_{k+1}^{j} \delta_{k}$ Indust $_{i t}+\epsilon_{i t}$ Foreign\%

\begin{tabular}{lcc}
\hline & Coef. & \multicolumn{1}{c}{-stat. } \\
\hline Constant & 0.103 & 0.624 \\
DivTC & -0.123 & $-3.569 * * *$ \\
Size & 0.001 & 0.197 \\
ROA & 0.052 & 0.241 \\
LEV & 0.119 & 0.991 \\
CAPINT & -0.213 & $-2.330 *$ \\
RDINT & -0.605 & -0.550 \\
INTAN & -0.032 & -0.636 \\
TotalAccruals & -0.209 & -1.047 \\
Energy & 0.165 & 1.698 \\
Materials & 0.062 & 2.177 \\
Industrials & 0.053 & 1.599 \\
Consumer Discretionary & 0.049 & 1.953 \\
Consumer Staples & 0.019 & 0.531 \\
Health Care & 0.057 & 1.652 \\
Information Technology & -0.029 & -0.867 \\
Telecommunications & 0.019 & 0.432 \\
\hline Observations & 196 & \\
R-squared & 0.208 & \\
Adjusted R-squared & 0.137 & \\
F-Stat. & 2.616 & \\
Year Fixed Effects & Yes & \\
\hline
\end{tabular}

$* \mathrm{p}<0.05, * * \mathrm{p}<0.01, * * * \mathrm{p}<0.001$

Where:

DivTC $_{i t} \quad$ : Dichotomous variable assuming the value 1 if firm $i$ pays a dividend with a tax credit in year $t$, else 0 .

Foreign $\%$ : $\quad$ Percent of shares held by non-resident shareholders for firm $\mathrm{i}$ in 2015 
Table 7: Effects of Global Financial Crisis

CashETR

\begin{tabular}{|c|c|c|c|}
\hline & & & \\
\hline & Coef. & t-stat. & \\
\hline Constant & -0.083 & -2.065 & $*$ \\
\hline DivTC & 0.157 & 5.641 & $* * *$ \\
\hline DivNTC & -0.021 & -1.737 & \\
\hline Outside\% & -0.077 & -2.060 & $*$ \\
\hline Outside\%*DivTC & -0.042 & -0.863 & \\
\hline Post-GFC & 0.051 & 2.682 & $* *$ \\
\hline PostGFC*DivTC & -0.017 & -1.332 & \\
\hline Size & 0.012 & 5.938 & $* * *$ \\
\hline$R O A$ & -0.002 & -1.395 & \\
\hline$L E V$ & -0.031 & -1.362 & \\
\hline CAPINT & 0.080 & 3.049 & $* *$ \\
\hline RDINT & 0.081 & 1.075 & \\
\hline INTAN & 0.109 & 6.410 & $* * *$ \\
\hline TotalAccruals & -0.026 & -1.351 & \\
\hline Observations & 4729 & & \\
\hline R-squared & 0.155 & & \\
\hline Adjusted R-squared & 0.149 & & \\
\hline F-Stat. & 35.69 & & \\
\hline Industry Fixed Effects & Yes & & \\
\hline Year Fixed Effects & Yes & & \\
\hline
\end{tabular}

${ }^{*} p<0.5 ; * * p<0.01 ; * * * p<0.001$ 
Table 8: Propensity Score Matching

\begin{tabular}{|c|c|c|c|c|c|c|c|c|c|c|c|c|c|c|c|}
\hline & & & & & & & \multicolumn{9}{|c|}{ Matched Sample } \\
\hline & \multicolumn{3}{|c|}{ Baseline } & \multicolumn{3}{|c|}{$\mathrm{BL}+$ controls } & Nea & est & & Radius & $(0.1)$ & & Ker & & \\
\hline & Coef. & t-stat & & Coef. & t-stat & & Coef. & t-stat & & Coef. & t-stat & & Coe7. & t-stat & \\
\hline DivTC & 0.158 & 24.84 & $* * *$ & 0.133 & 19.06 & $* * *$ & 0.132 & 11.24 & $* * *$ & 0.137 & 17.65 & $* * *$ & 0.119 & 14.13 & $* * *$ \\
\hline Std. Err. & 0.006 & & & 0.007 & & & 0.012 & & & 0.008 & & & 0.008 & & \\
\hline Obs. & 4729 & & & 4729 & & & 4729 & & & 4729 & & & 4729 & & \\
\hline
\end{tabular}

$* p<0.5 ;{ }^{* *} p<0.01 ; * * * p<0.001$

Table 9: Fama-MacBeth Regressions

\begin{tabular}{|c|c|c|c|c|c|c|c|c|c|}
\hline & $\begin{array}{c}(1) \\
\text { CashETR } \\
\text { Coef. }\end{array}$ & t-stat. & & $\begin{array}{c}(2) \\
\text { CashETR } \\
\text { Coef. }\end{array}$ & t-stat. & & $\begin{array}{c}(3) \\
\text { CashETR } \\
\text { Coef. }\end{array}$ & t-stat. & \\
\hline Constant & -0.040 & -1.289 & & -0.040 & -1.315 & & -0.069 & -2.127 & $*$ \\
\hline DivTC & 0.125 & 17.389 & $* * *$ & 0.125 & 21.001 & $* * *$ & 0.126 & 16.246 & $* * *$ \\
\hline DivNTC & -0.027 & -2.193 & & -0.027 & -2.082 & & -0.024 & -2.021 & $*$ \\
\hline Size & 0.008 & 4.785 & $* * *$ & 0.008 & 4.963 & $* * *$ & 0.009 & 5.036 & $* * *$ \\
\hline$R O A$ & -0.030 & -1.812 & & -0.030 & -2.235 & $*$ & -0.002 & -1.037 & \\
\hline$L E V$ & -0.018 & -0.770 & & -0.018 & -0.747 & & -0.015 & -0.624 & \\
\hline CAPINT & 0.062 & 2.510 & $*$ & 0.062 & 3.718 & $* *$ & 0.074 & 2.953 & $* *$ \\
\hline RDINT & 0.031 & 0.354 & & 0.031 & 0.284 & & -0.006 & -0.066 & \\
\hline INTAN & 0.098 & 6.917 & $* * *$ & 0.098 & 7.734 & $* * *$ & 0.107 & 7.130 & $* * *$ \\
\hline TotalAccruals & -0.116 & -3.421 & $* *$ & -0.116 & -3.782 & $* *$ & -0.027 & -2.780 & $* *$ \\
\hline Observations & 4729 & & & 4729 & & & 4729 & & \\
\hline R-squared & 0.166 & & & 0.166 & & & 0.135 & & \\
\hline
\end{tabular}


